\title{
Green Synthesis of Heterogeneous Visible-Light-Active Photocatalysts: Recent Advances
}

\author{
Alessio Zuliani * and Camilla Maria Cova \\ Center for Colloid and Surface Science (CSGI) \& Department of Chemistry, University of Florence, Via della \\ Lastruccia 3, Sesto Fiorentino, 50019 Florence, Italy; cova@csgi.unifi.it \\ * Correspondence: zuliani@csgi.unifi.it
}

\begin{abstract}
The exploitation of visible-light active photocatalytic materials can potentially change the supply of energy and deeply transform our world, giving access to a carbon neutral society. Currently, most photocatalysts are produced through low-ecofriendly, energy dispersive, and fossil-based synthesis. Over the last few years, research has focused on the development of innovative heterogeneous photocatalysts by the design of sustainable and green synthetic approaches. These strategies range from the use of plant extracts, to the valorization and recycling of metals inside industrial sludges or from the use of solventless techniques to the elaboration of mild-reaction condition synthetic tools. This mini-review highlights progresses in the development of visible-light-active heterogeneous photocatalysts based on two different approaches: the design of sustainable synthetic methodologies and the use of biomass and waste as sources of chemicals embedded in the final photoactive materials.
\end{abstract}

Keywords: photocatalysis; visible light; biomass; waste; green chemistry; nanocatalysis

check for updates

Citation: Zuliani, A.; Cova, C.M. Green Synthesis of Heterogeneous Visible-Light-Active Photocatalysts: Recent Advances. Photochem 2021, 1, 147-166. https://doi.org/ photochem1020009

Received: 18 June 2021

Accepted: 20 July 2021

Published: 27 July 2021

Publisher's Note: MDPI stays neutral with regard to jurisdictional claims in published maps and institutional affiliations.

Copyright: (c) 2021 by the authors. Licensee MDPI, Basel, Switzerland. This article is an open access article distributed under the terms and conditions of the Creative Commons Attribution (CC BY) license (https:/ / creativecommons.org/licenses/by/ $4.0 /)$.

\section{Introduction}

Photochemistry plays a crucial role in the so-defined "Earth green transition", i.e., the transition towards a climate-neutral economy [1,2]. Indeed, thanks to photocatalytically active materials, it is possible to exploit sunlight as an energetical source for unlimited functions ranging from the evolution of hydrogen through water splitting to the degradation of pollutants or to photopolymerization [3-8]. Considering that the sun continuously irradiates the planet with 120,000 terawatts, amounting to almost 6000 times the Earth's energy consumption, the potentialities of photochemistry are really unlimited [9]. However, the direct use of sunlight is still poorly exploited, while the use of the "stocked" form of solar energy, i.e., fossil fuels, represents the main power source of humanity. Indeed, the sun has been giving energy (in the form of light and heat) to the planet for over 4.5 billion years, and this irradiation has been captured and chemically transformed into fossil fuels over millions of years. Despite the sun being expected to keep shining on the Earth for at least another four billion years before becoming a full-blown giant red star whose brightness will burn the planet, the rate of production of fossil fuels is enormously slower that the rate of consumption. As a result, fossil fuels are classified as non-renewable resources (at least on a decade-scale and not on an eon-scale) [10]. Furthermore, and more importantly, the use of fossil fuels implies the release, in just a few years, of carbon accumulated over millions of years [11]. This carbon emission, mainly in the form of carbon dioxide, is faster that the ability of the planet to "capture" and fix it again, with the consequence of an atmosphere filled with carbon dioxide. A truly novel situation for mankind, generating unexpected consequences [12-15]. As a result, sunlight should be exploited in a faster and more direct way. One option could be the proper use of biomass, which is one of the greenest ways to produce energy-in the (direct) form of electricity (e.g., by burning biomass) or as hydrogen, chemical products, and biodiesels, among others $[16,17]$. It should be noted that, similar to the use of fossil fuels, the use of biomass consists of exploiting solar energy already converted into chemical bonds by the action of chlorophyll, 
i.e., nature's photocatalyst, but in the form of renewable and carbon neutral resources. However, the use of biomass entails some important limits, such as the possible detriment of food production or, as in the case of the use of biodiesel, the release of particulates into the environment $[18,19]$. On the other hand, photochemistry offers, at least on a theoretical level, the possibility of directly using sunlight, avoiding all the drawbacks rising from the utilization of biomass [20].

As a result, over the last few years, national and international policies, such as those by the UN or EU, but more importantly researchers' innovative spirit, have driven the investigation into visible light active photoactive materials for numerous achievements. Special focus should be put on photocatalysts developed by green and environmentally friendly synthesis. In fact, this approach follows the principles of sustainable development and fully fills the idea of green transition: there is no real benefit in developing a material with high photocatalytic activity, but with a negative impact on the environment due to its low-sustainable production. Many research groups have, therefore, developed different green and environmentally friendly photocatalysts, as summarized in recent reviews (Table 1).

Table 1. Recent reviews describing green photocatalytic materials.

\begin{tabular}{cc}
\hline \multicolumn{1}{c}{ Title } & Ref. \\
\hline $\begin{array}{c}\text { Bio-inspired and biomaterials-based hybrid photocatalysts for environmental } \\
\text { detoxification: A review }\end{array}$ & {$[21]$} \\
\hline $\begin{array}{c}\text { Green synthesis: Photocatalytic degradation of textile dyes using metal and } \\
\text { metal oxide nanoparticles-latest trends and advancements }\end{array}$ & {$[22]$} \\
\hline Recent Development of Photocatalysts Containing Carbon Species: A Review & {$[23]$} \\
\hline Graphene-Based Materials as Efficient Photocatalysts for Water Splitting & {$[24]$} \\
\hline Lignin-Based Composite Materials for Photocatalysis and Photovoltaics & {$[25]$} \\
\hline
\end{tabular}

The purpose of this mini-review is to provide a summary of the most recent insights into the development of innovative photocatalysts by focusing on visible light active materials prepared through the valorization of biomass and waste: as far as we know, a similar review is not present in the literature. In detail, this work describes, in two separate sections, photocatalysts produced via sustainable processes (i.e., focusing on the synthetic steps) and photocatalysts produced by englobing in the final product biomass or waste materials (i.e., using them as sources of chemicals).

\section{A Green Synthetic Approach}

A primary approach to producing sustainable photocatalysts is through environmentally friendly and green synthesis. This approach follows, as much as possible, the 12 principles of green chemistry [26,27], and suggests a rapid solution for the sustainable preparation of photocatalysts.

According to the literature, a captivating method for the green synthesis of photocatalysts is the reduction as well as stabilization/capping of metal ions using different plant extracts with high content of polyphenols, or more in general of phytochemicals. This approach is clearly not limited to the production of photocatalysts, but is also exploited for the preparation of many other catalysts and materials, such as nanocatalysts, electrodes, etc. [28]. It has to be remarked that when vegetable extracts are used for the production of photocatalysts, sunlight can be considered the central core of the methodology, being the source of energy used for the production of the phytochemicals (though photosynthesis) and activation of the produced photocatalyst, as illustrated in Figure 1. 


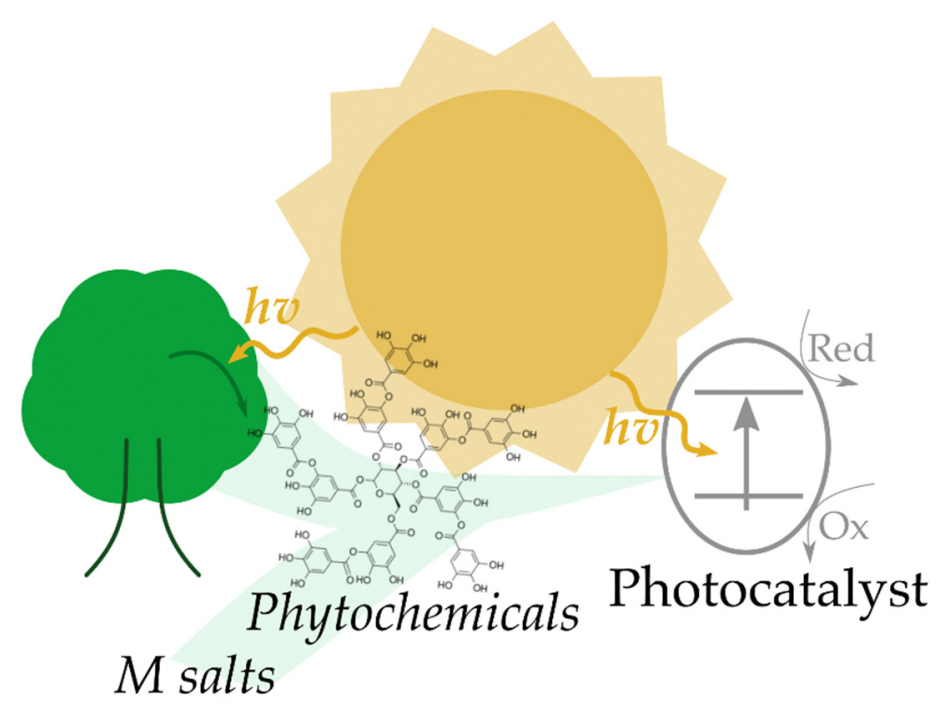

Figure 1. Conceptual illustration of the role of the sun in the synthesis of phytochemicals and the activation of photocatalysts produced using phytochemicals as stabilizing/reducing agents.

Other approaches include solventless techniques, such as using milling tools, the use of environmentally friendly reactants, the use of mild reaction conditions, etc. Between most studied photocatalysts, a special focus should be put on those based on silver, iron, zinc, and titanium dioxide, whether supported/in combination with other compounds or in their pure form.

\subsection{Silver-Based Photocatalsyts}

Recently, Bi et al. described a solid-state milling approach for the preparation of silver iodide/bismuth oxide acetate (AgI/BiOAc) [29]. In details, the novel photocatalyst was prepared via a facile, green, and environmentally friendly one-pot milling method. The photocatalyst showed enhanced visible-light photocatalytic performances for the degradation of different common dyes such as methyl violet, methyl orange, malachite green, and colorless bisphenol A, in comparison with the same compound prepared via a traditional method. The iodine content was demonstrated to be capable of optimizing the energy band structure while the in situ preparation of AgI/BiOAc resulted in the catalyst possess closely contacted interfaces, a beneficial effect for the transfer and recombination of electrons and holes.

More recently, Nehru and coworkers studied the synthesis of silver nanoparticles supported over titanium dioxide $\left(\mathrm{Ag} @ \mathrm{TiO}_{2}\right)$ using aloe vera (Aloe perfoliata) gel as a capping and reducing agent [30]. The material was tested in the photodegradation of picric acid under visible light irradiation. Additionally, anticancer activity against lung cancer cell lines was determined, and it was proved that the adsorption of visible light enhanced the anticancer sensitivity by killing and inhibiting cancer cell reproduction. Similarly, Ag nanoparticles, (40 nm average crystalline size according to XRD) showing photocatalytic and antimicrobial activity, were prepared using jasmine (Jasminum officinale) extract [31]. In more detail, the particles were synthesized through a simple, green, eco-friendly, nontoxic, and cost-effective method using the extract of jasmine flower as a capping and stabilizing agent. The so-synthesized particles showed good performances in the degradation of methyl blue, a standard dye for degradation test, under visible light irradiation. Additionally, the particles were proved to possess antimicrobial characteristics for both grams positive and negative bacteria. Other recently employed plant extracts for the synthesis of silver-based photocatalyst include Nìm (Azadirachta indica) tree fruit extract [32], solanum surattense (Solanum virginianum) leaves extract [33], chili (Capsicum annuum) extract [34], apple (from Malus domestica tree) and grape (from Vitis vinifera tree) extract [35], garlic (Allium sativum) extract [36], devil pepper (Rauvolfia tetraphylla) leaves extract [37], and small-flowered black 
hawthorn (Crataegus pentagyna) fruit extract [38]. Some plant extracts were also used for the preparation of different bimetallic photocatalysts, such $\mathrm{Ag} / \mathrm{CuO}$ [39]. In details, Cyperus pangorei leaves extract was used to synthetize $\mathrm{Ag} / \mathrm{CuO}$ nanoparticles by a co-precipitation method starting from $\mathrm{Cu}^{2+}$ and $\mathrm{Ag}^{2+}$ ions. The photocatalytic activity of $\mathrm{Ag} / \mathrm{CuO}$ was studied in the Rhodamine B dye degradation under visible light irradiation, proving that $\mathrm{Ag}$-doped with $\mathrm{CuO}$ improved the catalytic performances in comparison with pure $\mathrm{CuO}$. The material was also tested against Gram-positive (Staphylococcus aureus-S. aureus) and Gram-negative (Escherichia coli-E. coli) bacteria.

Another green synthetic approach for the preparation of silver-based photocatalyst involved an ion exchange approach [40]. Specifically, a novel plasmonic $\mathrm{Ag} @ \mathrm{AgVO}_{3} / \mathrm{BiVO}_{4}$ heterostructure was prepared via an in situ topotactic sustainable ion exchange-reduction method, as illustrated in Figure 2.

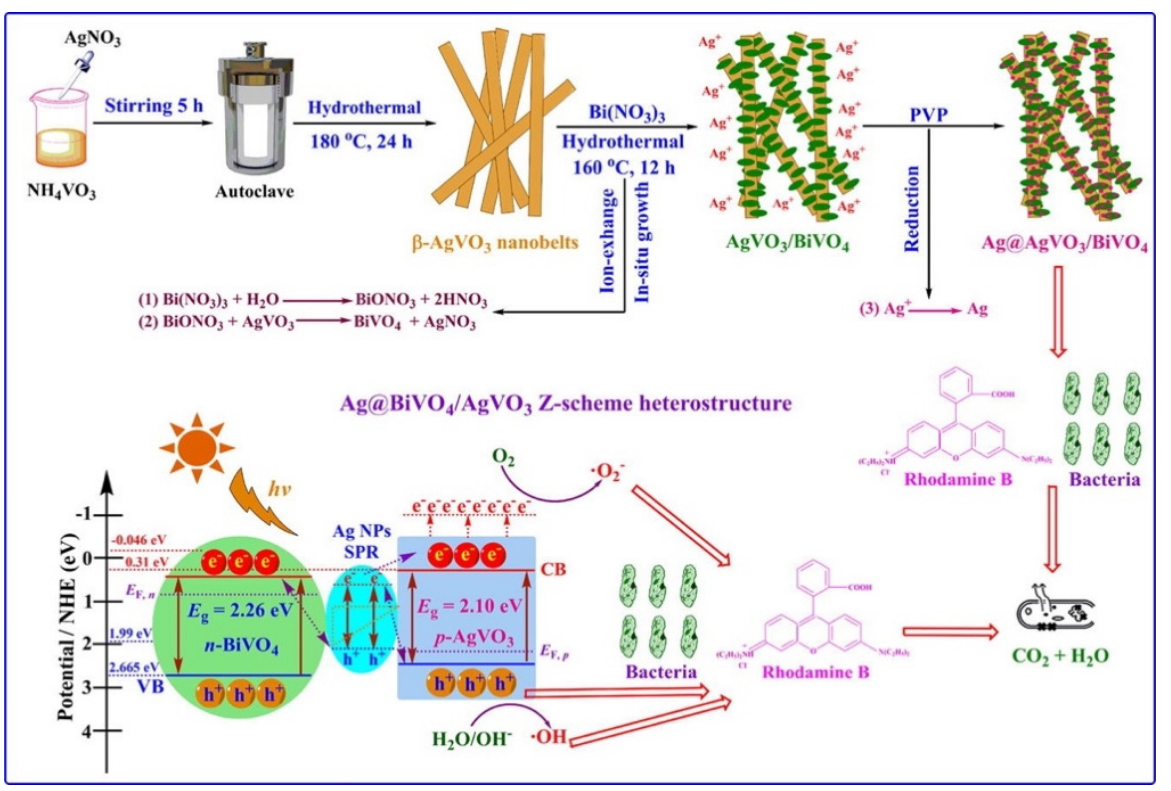

Figure 2. Schematic representation of preparation and utilization of $\mathrm{Ag} @ \mathrm{AgVO} 3 / \mathrm{BiVO}_{4}$ heterostructure. Taken from [40] with the permission of Elsevier.

The novel ternary heterostructure was composed of $\mathrm{AgVO}_{3}$ nanobelts loaded with $\mathrm{BiVO}_{4}$ nanosheets and $\mathrm{Ag}$ nanoparticles, which grew in situ on the surface of $\mathrm{AgVO}_{3}$ through a topotactic transformation with the assistance of polyvinylpyrrolidone (PVP). PVP not only made the recycling of Ag possible, but also induced a surface plasmon resonance effect in the composite, via a novel green approach. The photocatalytic tests for the degradation of rhodamine $\mathrm{B}$ indicated that the novel $\mathrm{Ag} @ \mathrm{AgVO} 3 / \mathrm{BiVO}_{4}$ composite material showed a significantly enhanced photocatalytic activity under visible light irradiation compared to $\mathrm{AgVO}_{3}, \mathrm{Ag} @ \mathrm{BiVO}_{4}$ and $\mathrm{Ag} @ \mathrm{AgVO}_{3} / \mathrm{BiVO}_{4}$. This behavior was ascribed to the SPR effect of Ag NPs and to the large specific surface area combined with the stable heterostructure. The photocatalyst was also demonstrated to possess antimicrobial properties.

Liu and coworkers proposed another green method for the preparation of silver nanoparticles $(50 \mathrm{~nm}$ ) supported on $\mathrm{AgCl}$ using microbial culture broths and visible light irradiation [41]. In detail, the nanoparticles were prepared by first forming a colloidal dispersion of $\mathrm{AgCl}$ in a microbe-free aqueous lysogeny broth (Miller) solution. Then, an in situ photoreduction driven by sunlight formed small plasmonic Ag@AgCl. The biomolecular ligands of the microbial solution broth worked as a promoter of the reduction process, making the formation of novel $\mathrm{Ag} @ \mathrm{AgCl}$ structures with improved photochemical activity possible. Remarkably, these structures were not obtainable via a standard chemical reduction process, as shown in Figure 3. 


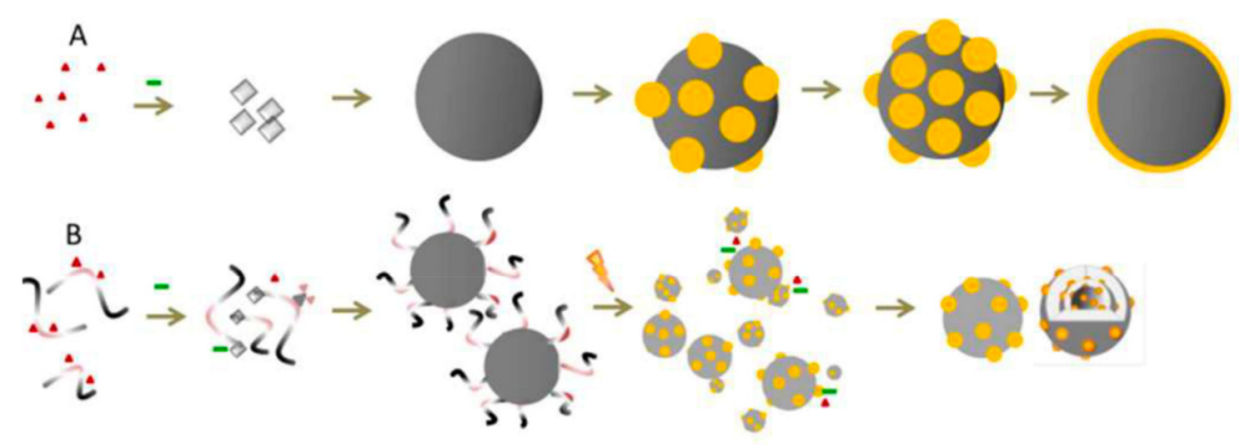

\section{$\Delta \mathrm{Ag}^{+}-\mathrm{Cl}^{-} \diamond \mathrm{AgCl}$ nuclei}

Figure 3. Schematic representation of the synthesis of $\mathrm{Ag} @ \mathrm{AgCl}$ : (A) Growth of $\mathrm{Ag} @ \mathrm{AgCl}$ in a typical chemical reduction process; (B) biogenic synthesis using microbial culture broths and photoreduction. Taken from [41] and reproduced by permission of The Royal Society of Chemistry.

Table 2 summarizes last works for the preparation of silver-based photocatalysts via sustainable synthetic approaches.

Table 2. Silver-based photocatalysts prepared through green synthetic approaches.

\begin{tabular}{|c|c|c|c|}
\hline Photocatalyst & Green Synthetic Approach & Application & Ref. \\
\hline $\mathrm{AgI} / \mathrm{BiOAc}$ & One-pot solventless milling approach & Dye degradation & [29] \\
\hline $\mathrm{Ag} / \mathrm{TiO}_{2}$ & $\begin{array}{l}\text { Use of plant extract gel (Aloe perfoliata) as a capping and } \\
\text { reducing agent }\end{array}$ & $\begin{array}{l}\text { Picric acid degradation; } \\
\text { anticancer activity }\end{array}$ & [30] \\
\hline Ag nanoparticles & $\begin{array}{l}\text { Use of leaves extract (Jasminum officinale) as a capping and } \\
\text { stabilizing agent }\end{array}$ & $\begin{array}{l}\text { Dye degradation; } \\
\text { antimicrobial activity }\end{array}$ & [31] \\
\hline $\mathrm{Ag} / \mathrm{AgCl}$ nanocomposites & $\begin{array}{l}\text { Use of fruit extract (Azadirachta indica) as a capping and } \\
\text { stabilizing agent }\end{array}$ & $\begin{array}{l}\text { Dye degradation; } \\
\text { antimicrobial activity }\end{array}$ & [32] \\
\hline Ag nanoparticles & $\begin{array}{l}\text { Use of leaves extract (Solanum virginianum) as a stabilizing } \\
\text { and reducing agent }\end{array}$ & $\begin{array}{l}\text { Dye degradation; antibacterial } \\
\text { activity }\end{array}$ & [33] \\
\hline $\mathrm{Ag} / \mathrm{Ag}_{2} \mathrm{O}$ nanoparticles & $\begin{array}{l}\text { Use of fruit extract (Capsicum annuum) as a stabilizing and } \\
\text { reducing agent }\end{array}$ & Dye degradation & [34] \\
\hline $\mathrm{Ag} / \mathrm{CuO}$ & $\begin{array}{c}\text { Use of leaves extract (Cyperus pangorei) as a stabilizing and } \\
\text { reducing agent }\end{array}$ & $\begin{array}{l}\text { Dye degradation; antibacterial } \\
\text { activity }\end{array}$ & [39] \\
\hline Ag nanoparticles & $\begin{array}{l}\text { Use of fruit extracts (Malus domestica and Vitis vinifera) as } \\
\text { stabilizing and reducing agents }\end{array}$ & $\begin{array}{l}\text { Dye degradation; antibacterial } \\
\text { activity }\end{array}$ & [35] \\
\hline $\mathrm{Ag} / \mathrm{CeO}_{2}$ & Use of plant extract (Allium sativum) as a stabilizing agent & $\begin{array}{l}\text { Dye degradation; antibacterial } \\
\text { activity }\end{array}$ & [36] \\
\hline Ag nanoparticles & $\begin{array}{c}\text { Use of leaves extract (Rauvolfia tetraphylla) as a stabilizing } \\
\text { agent }\end{array}$ & $\begin{array}{l}\text { Dye degradation; antibacterial } \\
\text { activity, LED preparation }\end{array}$ & [37] \\
\hline $\begin{array}{l}\mathrm{Fe}_{3} \mathrm{O}_{4} / \mathrm{SiO}_{2} / \mathrm{Cu}_{2} \mathrm{O}-\mathrm{Ag} \\
\text { nanocomposites }\end{array}$ & $\begin{array}{c}\text { Use of fruit extract (Crataegus pentagyna) as a capping and } \\
\text { reducing agent }\end{array}$ & $\begin{array}{l}\text { Magnetically recoverable } \\
\text { photocatalyst for dye } \\
\text { degradation }\end{array}$ & [38] \\
\hline $\begin{array}{l}\mathrm{Ag} @ \mathrm{AgVO}_{3} / \mathrm{BiVO}_{4} \\
\text { heterostructure }\end{array}$ & $\begin{array}{l}\text { Recycling of Ag during the synthetic step and introduction } \\
\text { of the surface plasmon resonance effect }\end{array}$ & $\begin{array}{l}\text { Dye degradation; antibacterial } \\
\text { activity }\end{array}$ & [40] \\
\hline $\mathrm{Ag} @ \mathrm{AgCl}$ & $\begin{array}{c}\text { Use of microbial culture broths (tryptic soy broth (TSB) and } \\
\text { Lysogeny broth (LB)) for enhancing the photoreduction of } \\
\text { silver precursor }\end{array}$ & Dye degradation & [41] \\
\hline
\end{tabular}




\subsection{Iron-Based Photocatalsyts}

The use of plant extracts is also largely employed for the preparation of iron-based photocatalysts. For example, photocatalytically active hematite nanorods, $\mathrm{Fe}_{2} \mathrm{O}_{3}$, were prepared using the resin of the stems of banana (Musa paradisiaca Linn) flowers [42]. During the one-pot synthetic phase, the natural resin acted as both an oxygen source as well as structure stabilizing agent. The so-obtained material was characterized with different techniques, and it was demonstrated that the rods have lengths between 528 and $72 \mathrm{~nm}$, as illustrated in SEM images in Figure 4. The photocatalytic efficiency of the catalyst was investigated by solar induced reduction of dichromate and degradation of malachite green as well as via photoelectrochemical water splitting experiments. In addition, the material was proved to possess potential to work against lung cancer.

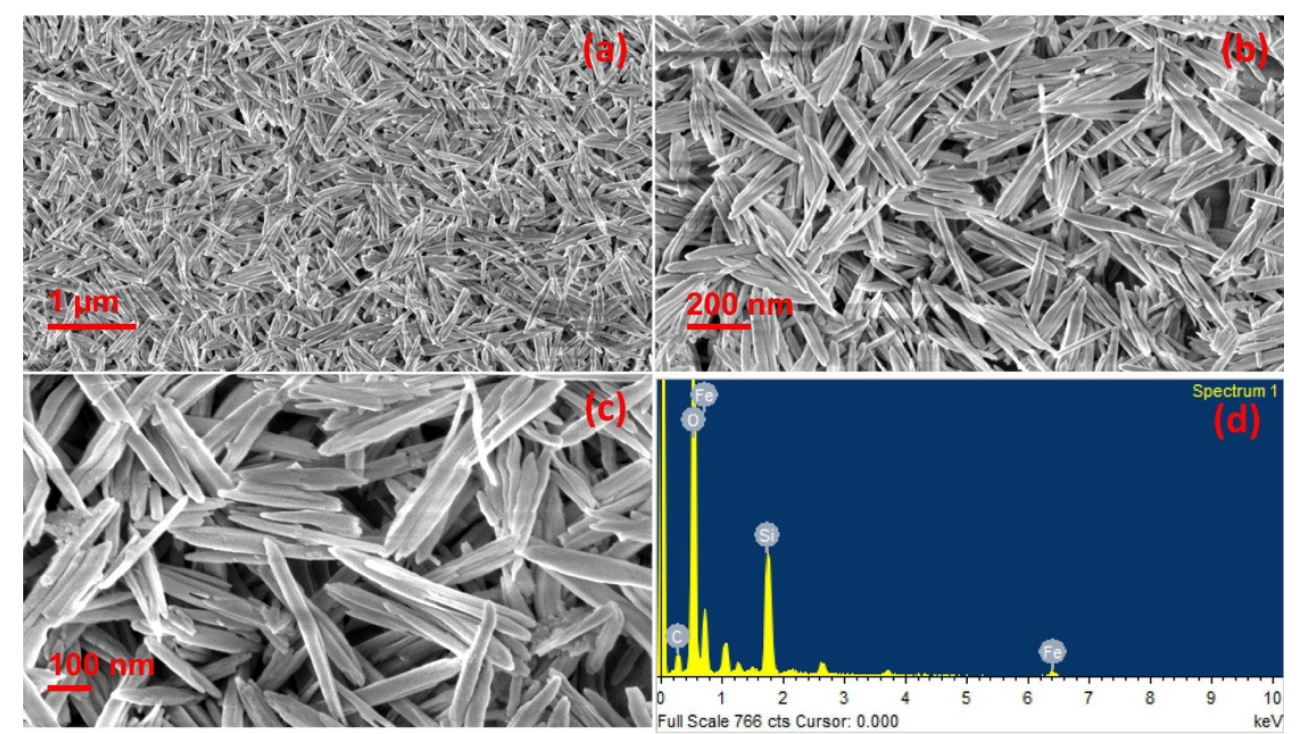

Figure 4. (a-c) SEM images of hematite nanorods and (d) EDS spectrum of the nanorods. Taken from [42] with the permission of Elsevier.

Aravind's research group developed a novel solution for the preparation of iron oxide nanoparticles using a waste generated from the avocado industry [43]. Specifically, phytochemicals found in avocado fruit (Persea americana) rind extract were used as reducing and stabilizing agent for the formation of iron nanoparticles starting from iron nitrate (III), in an eco-friendly and cost competitive method. The nanoparticles were employed as a photocatalyst for the decolorization of a sequence of different commonly employed dyes, including malachite green, Congo red, crystal violet, safranin, and methyl orange. In addition, the iron oxide nanoparticles showed antibacterial response against some Gram-negative and Gram-positive bacteria (such as Escherichia coli, Streptococcus sp., Staphylococcus sp., Salmonella sp., Bacillus sp., Pseudomonas sp. and Proteus sp.). Similarly, Rawat et al. prepared multi-structured $\mathrm{Fe}_{2} \mathrm{O}_{3}$ nanoparticles using Rhaphiolepis indicia leaves extracts. In detail, the eco-friendly green synthesis was carried out by using the hydroxyl groups of the polyphenols as a reducing agent, with the carboxyl and carbonyl groups as capping agents. Thanks to different characterization techniques, including XRD, FTIR, TEM and SEM, it was proved that multi-structured $\mathrm{Fe}_{2} \mathrm{O}_{3}$ was formed by nano-scaled hexagonal, rectangular slabs, pentagonal plates, and rods. The so-produced $\mathrm{Fe}_{2} \mathrm{O}_{3}$ nanostructure showed visible-light photocatalytic behavior for the degradation of Reactive Yellow-86 dye, a pollutant found in textile wastewater. The removal efficiencies were found to also be stable after five recycles, proving the good reusability of the photocatalyst [44].

Other natural extracts for the production of iron nanoparticles include, for example, billygoat-weed (Ageratum conyzoides) plant extract [45] or roselle (Hibiscus sabdariffa) flower 
extract [46]. Table 3 summarizes iron-based visible-light-active photocatalysts prepared using plant extracts.

Table 3. Iron-based photocatalysts prepared through green synthetic approaches.

\begin{tabular}{|c|c|c|c|}
\hline Photocatalyst & Green Synthetic Approach & Application & Ref. \\
\hline $\mathrm{Fe}_{2} \mathrm{O}_{3}$ nanorods & $\begin{array}{c}\text { Use of a natural resin (Musa Paradisiaca Linn) as an } \\
\text { oxygen source and stabilizing agent }\end{array}$ & $\begin{array}{c}\text { Dye degradation; } \\
\text { photoelectrochemical water } \\
\text { splitting; antibacterial activity }\end{array}$ & {$[42]$} \\
\hline Iron oxide nanoparticles & $\begin{array}{l}\text { Use of food waste (Persea americana) as a stabilizing } \\
\text { and reducing agent }\end{array}$ & $\begin{array}{l}\text { Dye degradation; antibacterial } \\
\text { activity }\end{array}$ & [43] \\
\hline $\begin{array}{l}\mathrm{Fe}_{3} \mathrm{O}_{4} \text { multistructured } \\
\text { nanoparticles }\end{array}$ & $\begin{array}{l}\text { Use of leaves extract (Rhaphiolepis indicia) as a } \\
\text { capping and reducing agent }\end{array}$ & Dye degradation & [44] \\
\hline Iron oxide nanoparticles & $\begin{array}{c}\text { Use of plant extract (Ageratum conyzoides) as a } \\
\text { stabilizing and reducing agent }\end{array}$ & $\begin{array}{c}\text { Dye degradation, antibacterial } \\
\text { activity }\end{array}$ & [45] \\
\hline Iron oxide nanoparticles & $\begin{array}{c}\text { Use of leaves extract (Hibiscus sabdariffa) as a } \\
\text { stabilizing and reducing agent }\end{array}$ & Dye degradation & [46] \\
\hline
\end{tabular}

\subsection{Zinc-Based Photocatalsyts}

The preparation of $\mathrm{ZnO}$ photocatalysts via green methodologies has received many attentions in the last decade [47]. More in details, the use of different natural extracts has gained interest due to the easiness of the preparation of $\mathrm{ZnO}$ nanoparticles employing them. It must be remarked that pure $\mathrm{ZnO}$ catalysts are active only in the UV region, due to their large band gap. However, recently proposed synthetic green solutions might be modified to prepare visible-light active doped/modified $\mathrm{ZnO}$ nanoparticles and deserve to be mentioned. For example, $\mathrm{ZnO}$ nanoparticles (with an average diameter of $18-25 \mathrm{~nm}$ ) were prepared by using the leaf extract of the plant Ruta chalepensis, as illustrated in Figure 5.

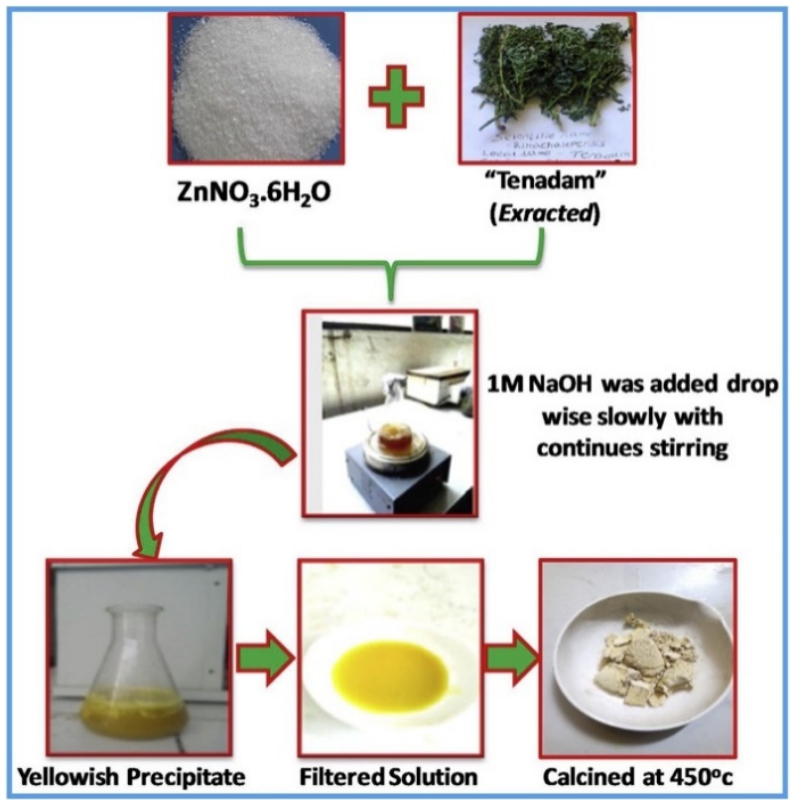

Figure 5. Schematic representation of the preparation and utilization of $\mathrm{ZnO}$ nanoparticles. Taken from [47] with the permission of Elsevier.

The material showed a band gap of $2.86 \mathrm{eV}$ (remarkably lower than the band gap of chemically synthetized $\mathrm{ZnO}$ of $3.35 \mathrm{eV}$ ) due to lower charge transfer resistance. 
Additionally, Yang and coworkers prepared $\mathrm{ZnO}$ nanoparticles with peculiar quaker ladies flower type structure using a mixture of extracts from different plants of the family Araliaceae [48]. In detail, the extract was derived from four of the roots of panax plants including Panax ginseng, Acanthopanax senticosus, Kalopanax septemlobus and Dendropanax morbifera. Similarly, Zheng et al. developed a synthesis of $\mathrm{ZnO}$ nanoparticles using roselle flower (Hibiscus sabdariffa) and oil palm (Elaeis guineensis) leaf extracts as stabilizing and reducing agents in combination with $\mathrm{NaOH}$ [49]. The particles were found to be in the size of 10-15 nm and in the form of agglomerated spherical shape. Other plant extracts used for the preparation of $\mathrm{ZnO}$ nanoparticles include, among others, Becium grandiflorum leaves extract, [50] sea buckthorn (Hippophae) fruit extract [51], sugar leaf (Stevia rebaudiana) extract [52], or Green tea [53].

In order to directly prepare visible-light active Zn-base photocatalysts, the researchers' efforts focused on the design of green methodologies for the simultaneous combination of different metals to produce composites/supported systems active under visible light irradiation.

For example, $\mathrm{p}-\mathrm{Co}_{3} \mathrm{O}_{4} / \mathrm{n}-\mathrm{ZnO}$ composite catalysts were produced by a co-precipitation method using hyacinth (Eichhornia Crassipes) plant extract [54]. The use of plant extract during the synthesis was proved to enhance the catalytic performances for the degradation of methylene blue under visible light irradiation. In addition, the formation of $p-n$ junction simplifies the photogenerated electron-hole separation and further improved the catalytic efficiency. With a similar approach, Shaheen and coworkers prepared $\mathrm{CuO} / \mathrm{ZnO}$ nanoparticles photocatalytically active for the degradation of methylene blue [55]. In details, they used a penicillin extract (Penicillium corylophilum As-1) to synthesize the photocatalyst in a fast, green, and easy way, as shown in Figure 6.

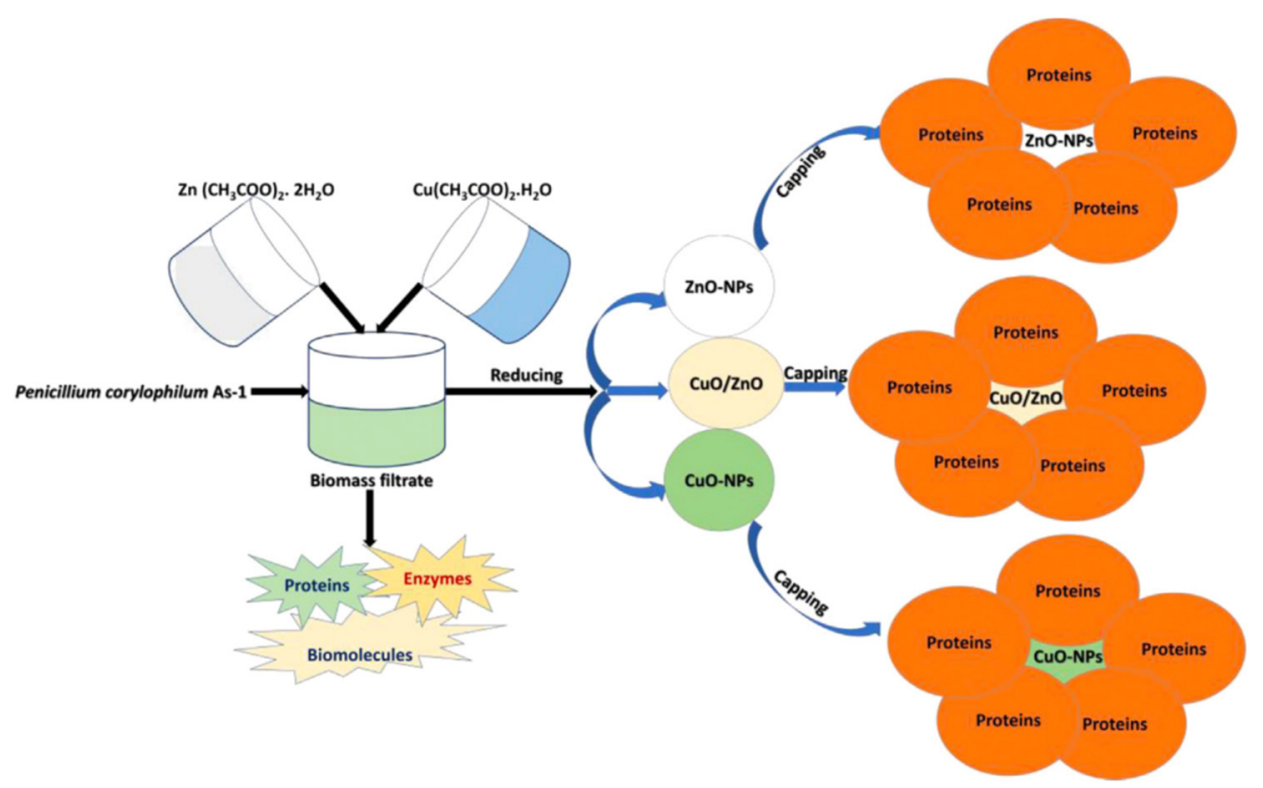

Figure 6. Schematic representation of the preparation and utilization of $\mathrm{CuO} / \mathrm{ZnO}$ nanoparticles. Taken from [55] with the permission of Elsevier.

Ag-ZnO nanocomposites (15-25 nm) were likewise prepared using potato peel extract (Solanum tuberosum) and used for dye degradation under visible light irradiation [56]. Other recently described green methodologies for the preparation of $\mathrm{ZnO}$ based photoactive composites include, as reported in Table 4, the preparation of Ag- $\mathrm{ZnO}$ nanoparticles using Excoecaria agallocha leaf extract under a controlled ultrasound cavitation technique [57], the synthesis of $\mathrm{ZnO} / \mathrm{GdCoO}_{3}$ nanocomposites in a two-phase system utilizing Myristica fragrans leaf extracts via a high-speed stirring method [58], the preparation of $\mathrm{Au}-\mathrm{ZnO}$ hetero-nanostructures using employing pecan nuts (Carya illinoinensis) leaves 
extract [59], or the synthesis of Co-doped $\mathrm{ZnO}$ through the accumulation of cobalt ion onto Eichhornia crassipes plant tissue for different days and combined with zinc [60].

Table 4. Zinc-based photocatalysts prepared through green synthetic approaches.

\begin{tabular}{|c|c|c|c|}
\hline Photocatalyst & Green Synthetic Approach & Application & Ref. \\
\hline $\mathrm{ZnO}$ nanoparticles & Use of leaves extract (Ruta chalepensis) as a stabilizing agent & $\begin{array}{l}\text { Dye degradation (UV } \\
\text { irradiation) }\end{array}$ & [47] \\
\hline $\mathrm{ZnO}$ nano-flowers & Use of roots extract (Araliaceae family) as a stabilizing agent & $\begin{array}{l}\text { Dye degradation (UV } \\
\text { irradiation) }\end{array}$ & [48] \\
\hline $\mathrm{ZnO}$ nanoparticles & $\begin{array}{l}\text { Use of leaves extract (Hibiscus sabdariffa and Elaeis guineensis) } \\
\text { as stabilizing agents }\end{array}$ & $\begin{array}{l}\text { Dye degradation (UV } \\
\text { irradiation) }\end{array}$ & [49] \\
\hline $\mathrm{ZnO}$ nanoparticles & $\begin{array}{c}\text { Use of leaves extract (Becium grandiflorum) as a stabilizing } \\
\text { agent }\end{array}$ & $\begin{array}{c}\text { Dye degradation (UV } \\
\text { irradiation); antimicrobial } \\
\text { activity }\end{array}$ & {$[50]$} \\
\hline $\mathrm{ZnO}$ nanoparticles & Use of fruit extract (Hippophae) as a stabilizing agent & $\begin{array}{l}\text { Dye degradation (UV } \\
\text { irradiation) }\end{array}$ & [51] \\
\hline $\mathrm{ZnO}$ nanoparticles & Use of leaves extract (Stevia rebaudiana) as a stabilizing agent & $\begin{array}{l}\text { Dye degradation (UV } \\
\text { irradiation) }\end{array}$ & {$[52]$} \\
\hline $\mathrm{Zn}-\mathrm{TiO}_{2}$ & Use of plant extract (Green Tea) as a reducing agent & $\begin{array}{l}\text { Dye degradation (UV } \\
\text { irradiation) }\end{array}$ & [53] \\
\hline $\mathrm{p}-\mathrm{Co}_{3} \mathrm{O}_{4} / \mathrm{n}-\mathrm{ZnO}$ & $\begin{array}{l}\text { Use of plant extract (Eichhornia Crassipes) as a stabilizing } \\
\text { and oxygen source agent }\end{array}$ & Dye degradation & {$[54]$} \\
\hline $\mathrm{CuO} / \mathrm{ZnO}$ nanoparticles & $\begin{array}{l}\text { Use of fungi extract (Penicillium corylophilum As-1) as a } \\
\text { stabilizing and reducing agent }\end{array}$ & Dye degradation & [55] \\
\hline Ag-ZnO nanocomposites & $\begin{array}{c}\text { Use of plant extract (Solanum tuberosum) as a stabilizing and } \\
\text { reducing agent }\end{array}$ & Dye degradation & [56] \\
\hline Ag-ZnO nanoparticles & $\begin{array}{c}\text { Use of leaves extract (Excoecaria agallocha) as a stabilizing } \\
\text { agent }\end{array}$ & $\begin{array}{l}\text { Dye degradation; antibacterial } \\
\text { activity }\end{array}$ & [57] \\
\hline $\begin{array}{l}\mathrm{ZnO} / \mathrm{GdCoO}_{3} \\
\text { nanocomposites }\end{array}$ & $\begin{array}{c}\text { Use of leaves extract (Myristica fragrans) as a stabilizing } \\
\text { agent }\end{array}$ & Dye degradation & [58] \\
\hline $\begin{array}{l}\mathrm{Au}-\mathrm{ZnO} \\
\text { hetero-nanostructures }\end{array}$ & $\begin{array}{l}\text { Use of leaves extract (Carya illinoinensis) as a stabilizing } \\
\text { agent }\end{array}$ & Dye degradation & [59] \\
\hline $\mathrm{Co} / \mathrm{ZnO}$ & $\begin{array}{l}\text { Use of Eichhornia crassipes plant tissue for the accumulation } \\
\text { of Co and sequential combination with } \mathrm{ZnO}\end{array}$ & Dye degradation & {$[60]$} \\
\hline
\end{tabular}

\subsection{Titanium Dioxide-Based Photocatalsyts}

The synthesis of titanium dioxide, perhaps the most studied photocatalytic compound $[4,5,61-66]$, has greatly evolved in the past years, and numerous green and sustainable synthetic approaches have been proposed. For example, recently, Tayebi et al. prepared $\mathrm{TiO}_{2}$ based on hexagonal mesoporous silicate (HMS) and loaded by different concentrations of natural polyphenol oak gall tannin [67]. The use of tannin prevented the aggregation of $\mathrm{TiO}_{2}$ nanoparticles, resulting in an enhanced photocatalytic performance for the degradation of an anionic dye (i.e., Direct yellow 86, used in paper and textile industries). Many other plant extracts have been proposed as capping, stabilizing, and reducing agents, for the production of $\mathrm{TiO}_{2}$ nanoparticles [68-72], while other approaches include, for example, solventless mechanochemical techniques [73,74]. Wang and coworkers prepared colored $\mathrm{TiO}_{2}$ (green, gray, orange, and yellow) through a novel mechanochemical method consisting of milling titanium dioxide with or without melamine [75]. As shown in Figure 7, the so-prepared materials showed some or all the phases of titanium dioxide. 


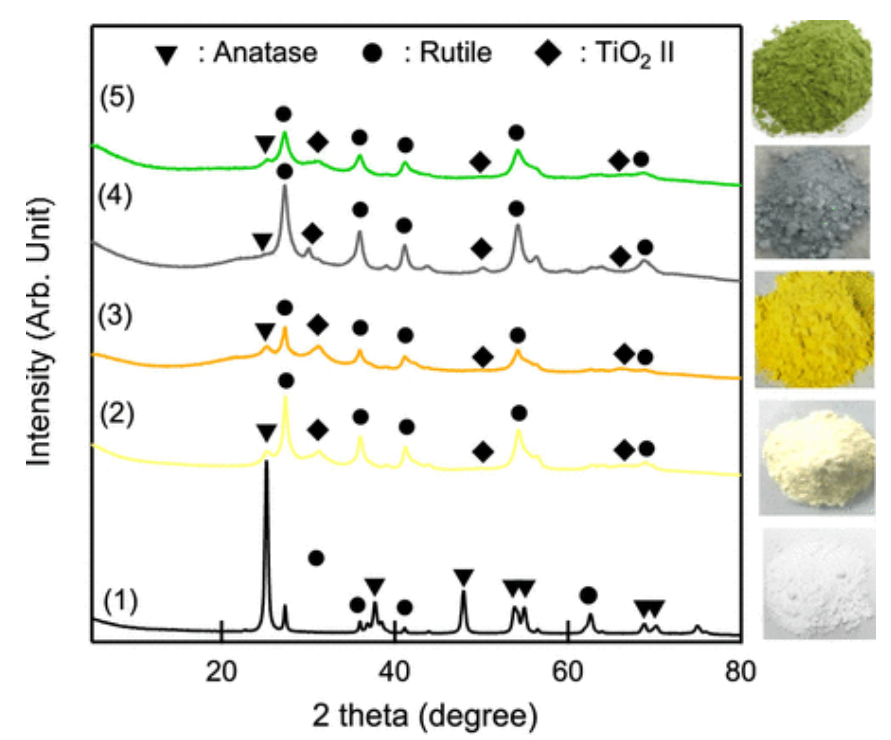

Figure 7. XRD patterns (plus photographs) of $\mathrm{TiO}_{2}$ produced via mechanochemical approach. (1) Commercially available $\mathrm{TiO}_{2}$ P25 before ball milling, (2) P25 milled in air, (3) P25 milled with melamine in air, (4) P25 milled in Ar, and (5) P25 milled with melamine in Ar; taken from [75] Copyright (2020), American Chemical Society.

The different colors derived from the reduced $\mathrm{Eg}(\sim 2.3 \mathrm{eV})$ and the presence of chemical and physical dopants and tailored the photocatalytic activity. $\mathrm{TiO}_{2}$ photocatalyst were tested in the degradation of methyl red under visible light irradiation, and no loadings, such as noble metals, metals, and metal oxides were needed. Notably, the materials had a photocatalytic activity up to five-time higher than commercially available $\mathrm{P} 25 \mathrm{TiO}_{2}$.

\subsection{Miscellaneous}

Other photocatalysts prepared via green and sustainable synthesis include composites made of different oxides, such as Cerium Oxide [76], Copper Oxide [77-79], Tin Oxide [80], or Bismuth Vanadate [81]. For example, Raki et al. [76] prepared pure $\mathrm{CeO}_{2} \mathrm{Mn} / \mathrm{CeO}_{2}$ nanocatalsyts (9-11 nm) using seed extract of Senna Alexandrina (Cassia angustifolia) as reducing and capping agents.

\section{A Focus on Materials: Waste and Bioderived Materials}

A second important approach for the preparation of green photocatalysts involves the use of biomass or waste as sources of chemicals during the synthetic steps. Differently from the first approach, described as the design of sustainable and environmentally friendly synthesis, this latter methodology focuses primary on the sources of materials for the preparation of photocatalysts. This approach strongly improves the sustainability of a process, as it could produce a photocatalyst (with all the benefits reported in the introduction section) by exploiting largely available (i.e., biomass) or scarcely/non-valorized (i.e., waste) materials. The photocatalytically active systems prepared using this tactic may be divided into materials derived from biomass and waste used as sources of carbon, and materials derived from waste and biomass used as sources of other chemicals, as schematically illustrated in Figure 8. 


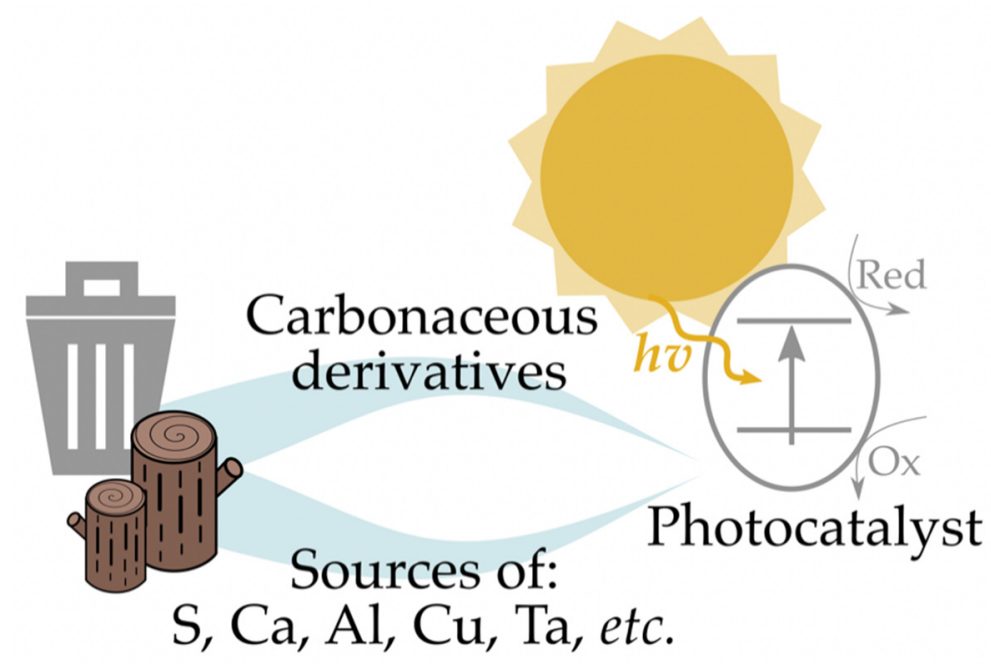

Figure 8. Conceptual valorization of waste and biomass to photocatalyst by exploitation of carbon or other chemicals content.

\subsection{Biomass and Waste as Sources of Carbon}

The most diffuse method for the preparation of biomass / waste-based photocatalysts is centered on the utilization of carbonaceous materials such as activated carbon, carbon dots, carbon nanotube/nanofiber, graphene, fullerene, $\mathrm{g}-\mathrm{C}_{3} \mathrm{~N}_{4}$, and carbon sponges/aerogels, derived from a large variety of biomass or waste [82-91]. For example, in a very recent work, a C-ZnO/ $\mathrm{MoS}_{2} /$ mesoporous carbon nanocomposite was successfully prepared by a two-step solution-processed synthetic protocol using sucrose as a carbon source for the preparation of a mesoporous carbonaceous supporting material [92]. The novel ternary composite exhibited a well-interconnected 3D mesoporous microstructure assembled by carbon nanosheets, loaded with quasi zero-dimensional $\mathrm{ZnO}$ nanoparticles and two-dimensional $\mathrm{MoS}_{2}$ nanosheets. The material showed enhanced visible-light-driven photocatalytic performance with remarkably high photo-corrosion resistance, as demonstrated by photodegradation tests of methyl orange (Figure 9).
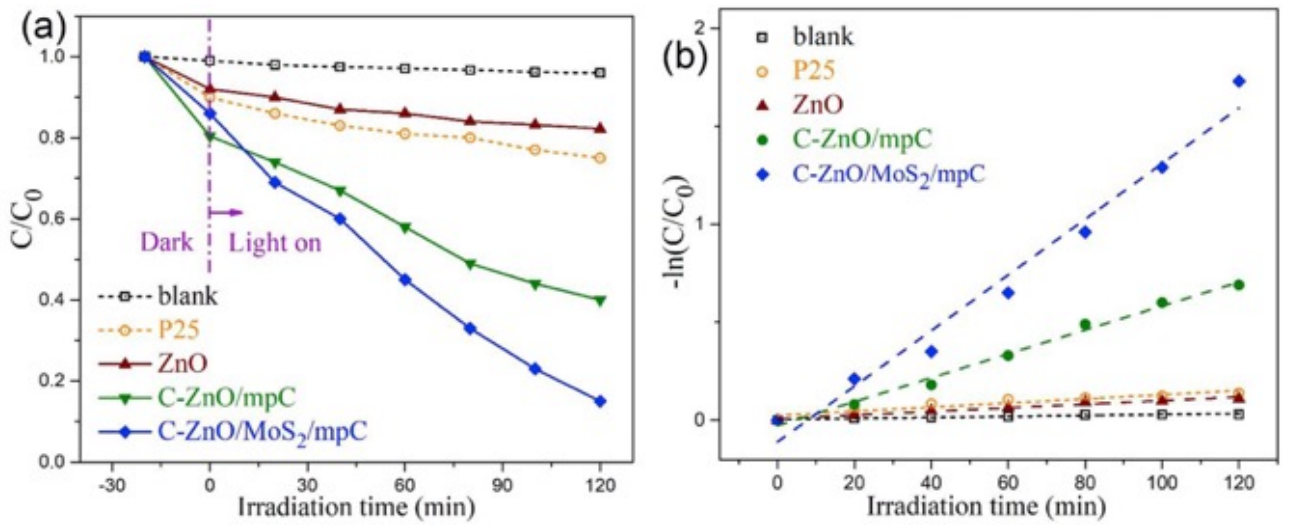

Figure 9. Photodegradation tests for methyl orange degradation using $\mathrm{C}-\mathrm{ZnO} / \mathrm{MoS}_{2} / \mathrm{mesoporous}$ carbon nanocomposite. (a) Relative concentrations (C/C0) of methyl orange as a function of the irradiation time under visible-light irradiation; (b) kinetic plots. Taken from [92] with the permission of Elsevier.

Importantly, the incorporation of carbon in the composite radically promoted the photoactivity and photostability of the photocatalyst, thanks to few positive synergistic effects, such as increased surface area and active reaction sites, boosted surface charge utilization efficiency, and lowered bandgap. 
$\mathrm{ZnO} /$ carbon xerogel composite were prepared using tannin as carbon source [93]. The diffuse reflectance test demonstrated that light absorption was significantly enhanced for the composite, while the solar light-driven photodegradation tests revealed that the synthesized composite achieved almost complete degradation of Rhodamine B.

Also, ternary Z-scheme C-doped graphitic carbon nitride/tungsten oxide (C-doped g- $\mathrm{C}_{3} \mathrm{~N}_{4} / \mathrm{WO}_{3}$ ) was successfully fabricated via an hydrothermal impregnation, using cellulose nanocrystal as carbon source [94]. The material exhibited narrower bandgap, enhanced visible-light absorption and separation of charge carrier, faster interfacial charge transfer, good oxidation/reduction capacities, and consequentially improved global photocatalytic activity performance.

Zhang's research group developed a novel graphitized carbon nitride photocatalysts using the desulfurized waste liquid extracting salt from coking plants, such as ammonium thiocyanate, ammonium thiosulfate, and ammonium sulfate. The addition of the salts provoked a large release of sulfur-containing gas during the pyrolysis, significantly increasing the specific surface area and the pore volume of the photocatalysts. In addition, pyrolysis with sulfur-containing salts resulted in the incorporation of sulfur in the carbon, widening the band gap of the photocatalysts to $2.94 \mathrm{eV}$ (i.e., enhancing its visible light activity). The photocatalysts showed improved NOx removal efficiency under visible light irradiation [95].

Despite the literature reporting many other types of visible light active carbonaceous photocatalysts derived from biomass or waste, such as a recently published ligninbased photocatalysts [96], a photocatalyst derived from wood flour waste (illustrated in Figure 10) [97], or a $\mathrm{MnFe}_{2} \mathrm{O}_{4}$-based photocatalyst supported over coal derived from industrially produced fly ash [98], or many others [99-101], specific insights about the preparation and utilization of these materials have already been fully described elsewhere and are not repeated here [23-25,102-105].

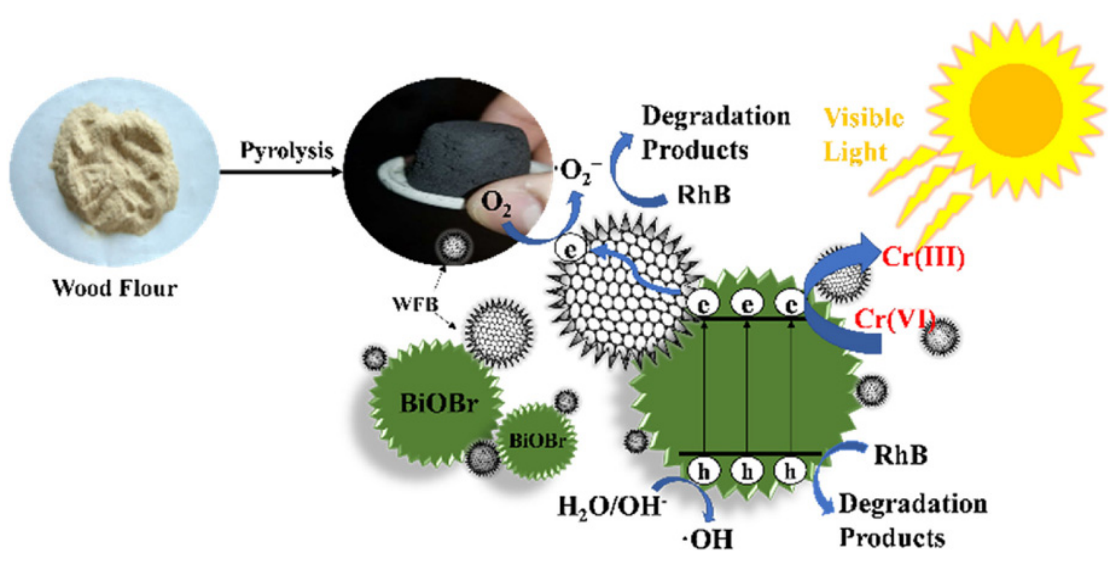

Figure 10. Synthesis and use of a carbonaceous photocatalyst derived from wood flour waste. Taken from [97] with the permission of Elsevier.

\subsection{Biomass and Waste as Sources of (Carbon) and Chemicals}

Beside the use of biomass or waste as mere sources of carbon, a more elaborated method consists in producing visible-light active photocatalysts using waste and biomass also as sources of other chemicals.

For example, in the past years, Luque's research group has developed different novel compounds using waste pig bristles as sulfur (present in the bristles in the form of cysteine, methionine, and cysteic acid) and carbon source, including photocatalytically active $\mathrm{Cu}_{2} \mathrm{~S}$ [106-108]. The photocatalysts was specifically prepared through a fast and easy microwave-assisted synthesis. $\mathrm{Cu}_{2} \mathrm{~S}$ showed a narrow bulk band gap of $1.2 \mathrm{eV}$ and was therefore tested for the degradation of methyl red under visible light irradiation, as shown in Figure 11. 


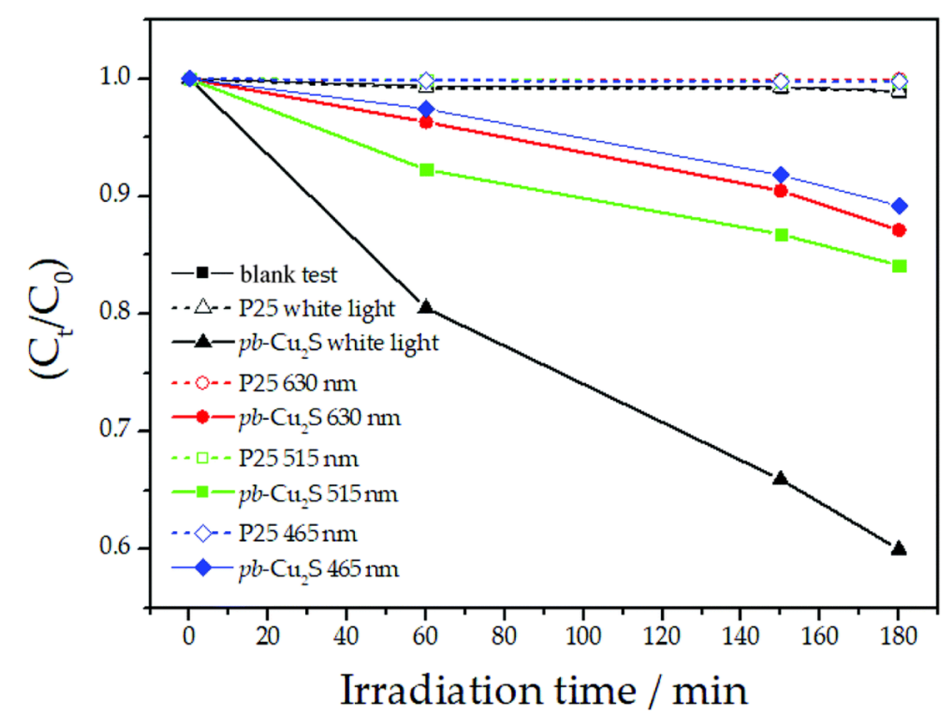

Figure 11. Photodegradation of methyl red catalyzed by $\mathrm{Cu}_{2} \mathrm{~S}$ produced from waste pig bristles as a function of time at different wavelength irradiation, taken from [106]. Reproduced by permission of The Royal Society of Chemistry.

The results demonstrated the possibility to prepare sulfide materials, with proved photocatalytic activity under visible light irradiation [109], with a largely produced waste (approximatively $225 \mathrm{k}$ ton of pig bristles are produced every year in the EU), which is still poorly valorized. Alternatively, other sulfides, such as iron sulfide (pyrite, $\mathrm{FeS}_{2}$ )-based photocatalysts can be produced using marcasite waste, a waste produced in the jewelry industry. According to Wasanapiarnpong et al., an iron sulfide-based photocatalysts can be used for the photocatalytic degradation of lignin [110].

In the last years, the literature has reported the use of waste eggshells as a source of calcium carbonate for the preparation of electrodes or many types of catalysts, including photocatalysts [111-115]. Indeed, eggshells are a waste largely produced in the dairy industry and its reuse and valorization could substitute the standardly employed low sustainable processes for their end-life treatment [116]. For example, calcium oxide nanoparticles were prepared using waste eggshells by a simple calcination process [117]. The so-produced nanoparticles were examined for the photocatalytic dye degradation of methylene blue and Toluidine blue in aqueous solutions. Remarkably, the catalyst could be recycled up to seven cycles without significant losses of activity.

Recently, Gil and coworkers developed a novel strategy for the recovery and reutilization of the aluminum present in the saline slags generated during Al processing [118]. With this approach the researchers prepared different valuable materials, proposing a sustainable alternative to the disposal of this waste sludge. For instance, they employed saline slags in a co-precipitation method to synthesize a sequence of samples containing zinc and various proportions of aluminum/titanium [119]. The materials were used as photocatalysts for the removal of diclofenac and salicylic acid (probably the most consumed non-steroidal anti-inflammatory drugs) from wastewater.

With a similar aim of valorizing an industrial waste, Ferretti et al., prepared nanometric $\mathrm{TiO}_{2}$-based magnetic catalyst using fly ash produced from the treatment of iron and steel [120]. The photocatalysts was prepared via a first one-step hydrothermal activation, during which the precursor was transformed into a zeolite with good magnetic properties, and sequentially $\mathrm{TiO}_{2}$ nanoparticles were supported on the zeolites through ultrasounds treatment. The photocatalytic activity of the novel catalysts was verified through the abatement of methylene blue.

Additionally, waste printed circuit boards (PCBs) can be used to produce photocatalysts. This type of recycling process can prevent the end life treatment of a largely-produced waste, since 20-50 million tons of waste electric and electronic equipment are produced 
worldwide each year [121]. For example, Qian's research group used PCBs as copper source to prepare a $\mathrm{Cu}_{2} \mathrm{O}$-basedphotocatalyst, and sequentially employed it for the photocatalytic reduction of $\mathrm{Cr}(\mathrm{VI})$ under visible light irradiation [122]. Similarly, the metals contained in waste capacitors can be reused to prepare $\mathrm{Ta}_{2} \mathrm{O}_{5}$ based or $\mathrm{BaTiO}_{3}$-based visible-light active photocatalysts $[123,124]$.

Table 5 reports last achievements in the development of visible-light-active photocatalysts using biomass and waste as chemical sources.

Table 5. Photocatalysts prepared through waste and biomass as sources of chemicals.

\begin{tabular}{|c|c|c|c|}
\hline Photocatalyst & Green Synthetic Approach & Application & Ref. \\
\hline $\mathrm{Cu}_{2} \mathrm{~S}$ & $\begin{array}{l}\text { Microwave assisted valorization of waste pig bristles } \\
\text { as a sulfur and carbon source }\end{array}$ & Dye degradation & [106] \\
\hline $\mathrm{FeS}_{2} /$ titanium dioxide & $\begin{array}{l}\text { Marcasite waste from jewelry industry as a source of } \\
\qquad \mathrm{FeS}_{2}\end{array}$ & Lignin degradation & [110] \\
\hline $\mathrm{CaO}$ & $\begin{array}{l}\text { Solvent free valorization of waste eggshells as a } \\
\text { calcium source }\end{array}$ & Dye degradation & [117] \\
\hline ZnTiFeAl-hydrotalcites & $\begin{array}{l}\text { Use of saline slags, generated during } \mathrm{Al} \text { processing, as } \\
\text { an } \mathrm{Al} \text { source }\end{array}$ & $\begin{array}{c}\text { Diclofenac and salicylic acid } \\
\text { degradation }\end{array}$ & [119] \\
\hline $\mathrm{Cu}_{2} \mathrm{O}$ & $\begin{array}{l}\text { Waste printed circuit boards (PCBs) as sources of } \\
\text { copper }\end{array}$ & Reduction of $\mathrm{Cr}(\mathrm{VI})$ & [122] \\
\hline $\mathrm{Ta}_{2} \mathrm{O}_{5}$-based photocatalyst & Waste capacitors as sources of Ta & Hydrogen production & [123] \\
\hline $\begin{array}{c}\text { Nb-Pb co-doped and } \\
\text { Ag-Pd-Sn-Ni loaded BaTiO3 }\end{array}$ & $\begin{array}{l}\text { Milling of waste capacitors (as sources of } \mathrm{BaTiO}_{3}, \mathrm{Ag} \text {, } \\
\qquad \mathrm{Pd}, \mathrm{Sn}, \mathrm{Ni}, \mathrm{Nb} \text {, and } \mathrm{Pb} \text { ) }\end{array}$ & Hydrogen production & [124] \\
\hline
\end{tabular}

\section{Summary and Outlook}

National and international policies as well as the public pressure for the shifting to a sustainable society are sensibly changing the research and development of materials. With no doubts, this change is also positively altering the design of new photocatalytic compounds. This mini-review has summarized some of the most recent and innovative approaches for the green production of visible-light-active photocatalysts, dividing the most recent works in function of the mere synthetic approach, i.e., with a focus on the sustainable characteristics of synthesis (e.g., the use of naturally derived nanoparticles stabilizing and reducing agents instead of classically used fossil-derived counterparts); or in function of the use of waste or biomass materials as sources of chemicals (e.g., the exploitation of waste slugs as sources of metals). All these methods have a common view of a transversal thinking aimed at avoiding low-eco-friendly procedures to produce materials (photocatalysts) designed for a green scope (i.e., Sun-driven photocatalysis). To date, researchers have proposed many innovative and out-of-the-box solutions for the green preparation of visible-light active photocatalysts, which further development may definitively change the way we know photochemistry. In addition, some investigation paths are still barely explored and may be open to the design of an infinitive number of new materials, such as in the case of the direct use of a waste as a photocatalyst (e.g., waste copper slag used as photocatalysts for the degradation of toxic alcohols) [125].

Nevertheless, major restrictions still limit the large-scale application of these novel materials. Indeed, the industrial manufacturing of green photocatalysts is still economically inconvenient and has no investor's interest. Clearly, fossil-based low-sustainable manufacturing procedures are too cheap to be substituted by procedures which scale-up have uncertain outcomes. Additionally, most of the world's chemical plants for the production of materials (in general) were designed to operate with high (or at least medium)-grade-purity raw materials, having intrinsic characteristics that are difficult to fund when operating with biomass or waste (considering also all troubles related to the different physical and chemical properties such as different viscosity, for example when operating with a solution 
of stabilizing agents such as EDTA in comparison with phenolic enriched solutions). It is quite obvious that the purification of biomass and waste, for example, for the selective extraction of chemicals (such as Sulphur in the case of [106]) will be even more complicated and increase the production costs of the so-derived photocatalysts (although they would probably be more active, due to the removal of impurities).

Finally, it should be mention that the practice of considering and evaluating the end-life treatment of the novel photocatalysts (or green synthetic approaches), as well as the determination of objective data of the overall sustainability of the processes, is still poorly diffused. Indeed, if on a hand all the discussed methods are claimed to decrease the environmental impact of the production of photocatalysts, on the other hand, any end-life considerations or at least any green metrics of the processes are rarely reported and discussed. Evidently, the use of biomass or waste during the processes could have positive effect on the environment, but these hypotheses should be supported by critical and objective factors. For example, green metrics such as E-Factor [126] can give a rapid and objective view of the sustainability of the process. Additionally, more detailed analysis, such as Life Cycle Assessments (LCA) [127], can deeply describe the potential impact of the novel photocatalysts on the environment. Parallelly, biodegradability or composability tests of the waste eventually produced during the preparation of the photocatalysts and may highlight critical aspects that must be modified. Additionally, some considerations of the production costs of the novel green photocatalysts in comparison with the standardly employed procedures should be described.

Author Contributions: Conceptualization, A.Z. and C.M.C.; writing-original draft preparation, A.Z. and C.M.C.; writing-review and editing, A.Z. and C.M.C.; supervision, A.Z. All authors have read and agreed to the published version of the manuscript.

Funding: This research received no external funding.

Institutional Review Board Statement: Not applicable.

Informed Consent Statement: Not applicable.

Conflicts of Interest: The authors declare no conflict of interest.

\section{References}

1. Skjaerseth, J.B. Towards a European Green Deal: The evolution of EU climate and energy policy mixes. Int. Environ. Agreem. Politics Law Econ. 2021, 21, 25-41. [CrossRef]

2. Ohnesorge, L.; Rogge, E. Europe's Green Policy: Towards a Climate Neutral Economy by Way of Investors' Choice. Eur. Co. Law 2021, 18, 34-39.

3. Kudo, A.; Miseki, Y. Heterogeneous photocatalyst materials for water splitting. Chem. Soc. Rev. 2009, 38, 253-278. [CrossRef] [PubMed]

4. Chiarello, G.L.; Zuliani, A.; Ceresoli, D.; Martinazzo, R.; Selli, E. Exploiting the Photonic Crystal Properties of TiO $2 \mathrm{Nanotube}^{-}$ Arrays To Enhance Photocatalytic Hydrogen Production. Acs Catal. 2016, 6, 1345-1353. [CrossRef]

5. Dozzi, M.V.; Chiarello, G.L.; Pedroni, M.; Livraghi, S.; Giamello, E.; Selli, E. High photocatalytic hydrogen production on Cu(II) pre-grafted Pt/TiO 2 . Appl. Catal. B Environ. 2017, 209, 417-428. [CrossRef]

6. Dutta, S.; Biswas, S.; Maji, R.C.; Saha, R. Environmentally Sustainable Fabrication of Cu1.94S-rGO Composite for Dual Environmental Application: Visible-Light-Active Photocatalyst and Room-Temperature Phenol Sensor. ACS Sustain. Chem. Eng. 2018, 6, 835-845. [CrossRef]

7. Lu, N.; Zhang, Z.; Wang, Y.; Liu, B.; Guo, L.; Wang, L.; Huang, J.; Liu, K.; Dong, B. Direct evidence of IR-driven hot electron transfer in metal-free plasmonic $\mathrm{W}_{18} \mathrm{O}_{49}$ /Carbon heterostructures for enhanced catalytic $\mathrm{H}_{2}$ production. Appl. Catal. B Environ. 2018, 233, 19-25. [CrossRef]

8. Lucena, R.; Conesa, J.C. V-Substituted $\mathrm{ZnIn}_{2} \mathrm{~S}_{4}$ : A (Visible+NIR) Light-Active Photocatalyst. Photochem 2021, 1, 1-9. [CrossRef]

9. Gratzel, M. Recent Advances in Sensitized Mesoscopic Solar Cells. Acc. Chem. Res. 2009, 42, 1788-1798. [CrossRef]

10. Zuliani, A.; Ivars, F.; Luque, R. Advances in Nanocatalyst Design for Biofuel Production. Chemcatchem 2018, $10,1968-1981$. [CrossRef]

11. Zhang, X.C.; Caldeira, K. Time scales and ratios of climate forcing due to thermal versus carbon dioxide emissions from fossil fuels. Geophys. Res. Lett. 2015, 42, 4548-4555. [CrossRef]

12. Fargione, J.; Hill, J.; Tilman, D.; Polasky, S.; Hawthorne, P. Land clearing and the biofuel carbon debt. Science 2008, 319, 1235-1238. [CrossRef] [PubMed] 
13. Held, I.M.; Soden, B.J. Robust responses of the hydrological cycle to global warming. J. Clim. 2006, 19, 5686-5699. [CrossRef]

14. Harley, C.D.G.; Hughes, A.R.; Hultgren, K.M.; Miner, B.G.; Sorte, C.J.B.; Thornber, C.S.; Rodriguez, L.F.; Tomanek, L.; Williams, S.L. The impacts of climate change in coastal marine systems. Ecol. Lett. 2006, 9, 228-241. [CrossRef]

15. Al-Ghussain, L. Global warming: Review on driving forces and mitigation. Environ. Prog. Sustain. Energy 2019, $38,13-21$. [CrossRef]

16. Okkerse, C.; van Bekkum, H. From fossil to green. Green Chem. 1999, 1, 107-114. [CrossRef]

17. Gao, M.M.; Zhu, L.L.; Peh, C.K.; Ho, G.W. Solar absorber material and system designs for photothermal water vaporization towards clean water and energy production. Energy Environ. Sci. 2019, 12, 841-864. [CrossRef]

18. Zhu, L.; Cheung, C.S.; Zhang, W.G.; Huang, Z. Effect of charge dilution on gaseous and particulate emissions from a diesel engine fueled with biodiesel and biodiesel blended with methanol and ethanol. Appl. Therm. Eng. 2011, 31, 2271-2278. [CrossRef]

19. Shukla, P.C.; Gupta, T.; Labhsetwar, N.K.; Agarwal, A.K. Trace metals and ions in particulates emitted by biodiesel fuelled engine. Fuel 2017, 188, 603-609. [CrossRef]

20. Balzani, V.; Credi, A.; Venturi, M. Photochemical conversion of solar energy. Chemsuschem 2008, 1, 26-58. [CrossRef]

21. Kumar, A.; Sharma, G.; Naushad, M.; Al-Muhtaseb, A.H.; Garcia-Penas, A.; Mola, G.T.; Si, C.L.; Stadler, F.J. Bio-inspired and biomaterials-based hybrid photocatalysts for environmental detoxification: A review. Chem. Eng. J. 2020, 382. [CrossRef]

22. Nagajyothi, P.C.; Vattikuti, S.V.P.; Devarayapalli, K.C.; Yoo, K.; Shim, J.; Sreekanth, T.V.M. Green synthesis: Photocatalytic degradation of textile dyes using metal and metal oxide nanoparticles-latest trends and advancements. Crit. Rev. Environ. Sci. Technol. 2020, 50, 2617-2723. [CrossRef]

23. Shi, Z.J.; Ma, M.G.; Zhu, J.F. Recent Development of Photocatalysts Containing Carbon Species: A Review. Catalysts 2019, 9, 20. [CrossRef]

24. Albero, J.; Mateo, D.; Garcia, H. Graphene-Based Materials as Efficient Photocatalysts for Water Splitting. Molecules 2019, 24, 906. [CrossRef] [PubMed]

25. Khan, A.; Nair, V.; Colmenares, J.C.; Glaser, R. Lignin-Based Composite Materials for Photocatalysis and Photovoltaics. Top. Curr. Chem. 2018, 376, 1-31. [CrossRef] [PubMed]

26. Anastas, P.T.; Bartlett, L.B.; Kirchhoff, M.M.; Williamson, T.C. The role of catalysis in the design, development, and implementation of green chemistry. Catal. Today 2000, 55, 11-22. [CrossRef]

27. Anastas, P.; Eghbali, N. Green Chemistry: Principles and Practice. Chem. Soc. Rev. 2010, 39, 301-312. [CrossRef]

28. Zuliani, A.; Cano, M.; Calsolaro, F.; Puente Santiago, A.R.; Giner-Casares, J.J.; Rodríguez-Castellón, E.; Berlier, G.; Cravotto, G.; Martina, K.; Luque, R. Improving the electrocatalytic performance of sustainable Co/carbon materials for the oxygen evolution reaction by ultrasound and microwave assisted synthesis. Sustain. Energy Fuels 2021, 5, 720-731. [CrossRef]

29. Jia, X.M.; Han, Q.F.; Zheng, M.Y.; Bi, H.P. One pot milling route to fabricate step-scheme AgI/I-BiOAc photocatalyst: Energy band structure optimized by the formation of solid solution. Appl. Surf. Sci. 2019, 489, 409-419. [CrossRef]

30. Hariharan, D.; Thangamuniyandi, P.; Christy, A.J.; Vasantharaja, R.; Selvakumar, P.; Sagadevan, S.; Pugazhendhi, A.; Nehru, L.C. Enhanced photocatalysis and anticancer activity of green hydrothermal synthesized Ag@ $\mathrm{TiO}_{2}$ nanoparticles. J. Photochem. Photobiol. B Biol. 2020, 202, 111636. [CrossRef] [PubMed]

31. Aravind, M.; Ahmad, A.; Ahmad, I.; Amalanathan, M.; Naseem, K.; Mary, S.M.M.; Parvathiraja, C.; Hussain, S.; Algarni, T.S.; Pervaiz, M.; et al. Critical green routing synthesis of silver NPs using jasmine flower extract for biological activities and photocatalytical degradation of methylene blue. J. Environ. Chem. Eng. 2021, 9, 104877. [CrossRef]

32. Panchal, P.; Meena, P.; Nehra, S.P. A rapid green synthesis of Ag/ AgCl-NC photocatalyst for environmental applications. Environ. Sci. Pollut. Res. 2021, 28, 3972-3982. [CrossRef]

33. Mani, M.; Chang, J.H.; Gandhi, A.D.; Vizhi, D.K.; Pavithra, S.; Mohanraj, K.; Mohanbabu, B.; Babu, B.; Balachandran, S.; Kumaresan, S. Environmental and biomedical applications of AgNPs synthesized using the aqueous extract of Solanum surattense leaf. Inorg. Chem. Commun. 2020, 121, 108228. [CrossRef]

34. El-Shabasy, R.; Yosri, N.; El-Seedi, H.; Shoueir, K.; El-Kemary, M. A green synthetic approach using chili plant supported $\mathrm{Ag} / \mathrm{Ag}_{2} \mathrm{O} @ \mathrm{P}_{25}$ heterostructure with enhanced photocatalytic properties under solar irradiation. Optik 2019, 192, 162943. [CrossRef]

35. Parthibavarman, M.; Bhuvaneshwari, S.; Jayashree, M.; BoopathiRaja, R. Green Synthesis of Silver (Ag) Nanoparticles Using Extract of Apple and Grape and with Enhanced Visible Light Photocatalytic Activity. Bionanoscience 2019, 9, 423-432. [CrossRef]

36. Ayodhya, D.; Veerabhadram, G. Green synthesis of garlic extract stabilized Ag@CeO $\mathrm{C}_{2}$ composites for photocatalytic and sonocatalytic degradation of mixed dyes and antimicrobial studies. J. Mol. Struct. 2020, 1205, 127611. [CrossRef]

37. Vinay, S.P.; Udayabhanu; Nagarju, G.; Chandrappa, C.P.; Chandrasekhar, N. Enhanced photocatalysis, photoluminescence, and anti-bacterial activities of nanosize Ag: Green synthesized via Rauvolfia tetraphylla (devil pepper). Sn Appl. Sci. 2019, 1, 1-14. [CrossRef]

38. Ebrahimzadeh, M.A.; Mortazavi-Derazkola, S.; Zazouli, M.A. Eco-friendly green synthesis and characterization of novel $\mathrm{Fe}_{3} \mathrm{O}_{4} / \mathrm{SiO}_{2} / \mathrm{Cu}_{2} \mathrm{O}-\mathrm{Ag}$ nanocomposites using Crataegus pentagyna fruit extract for photocatalytic degradation of organic contaminants. J. Mater. Sci. Mater. Electron. 2019, 30, 10994-11004. [CrossRef]

39. Parvathiraja, C.; Shailajha, S. Bioproduction of $\mathrm{CuO}$ and $\mathrm{Ag} / \mathrm{CuO}$ heterogeneous photocatalysis-photocatalytic dye degradation and biological activities. Appl. Nanosci. 2021, 11, 1411-1425. [CrossRef] 
40. Ju, P.; Wang, Y.; Sun, Y.; Zhang, D. In-situ green topotactic synthesis of a novel Z-scheme $\mathrm{Ag@AgVO} 3 / \mathrm{BiVO}_{4}$ heterostructure with highly enhanced visible-light photocatalytic activity. J. Colloid Interface Sci. 2020, 579, 431-447. [CrossRef]

41. Shen, Z.; Liu, B.; Pareek, V.; Wang, S.; Li, X.; Liu, L.; Liu, S. Sustainable synthesis of highly efficient sunlight-driven Ag embedded AgCl photocatalysts. Rsc Adv. 2015, 5, 80488-80495. [CrossRef]

42. Ramar, K.; Ahamed, A.J.; Muralidharan, K. Robust green synthetic approach for the production of iron oxide nanorods and its potential environmental and cytotoxicity applications. Adv. Powder Technol. 2019, 30, 2636-2648. [CrossRef]

43. Kamaraj, M.; Kidane, T.; Muluken, K.U.; Aravind, J. Biofabrication of iron oxide nanoparticles as a potential photocatalyst for dye degradation with antimicrobial activity. Int. J. Environ. Sci. Technol. 2019, 16, 8305-8314. [CrossRef]

44. Kaur, N.; Singh, J.; Kumar, S.; Singh, P.; Al-Rashed, S.; Kaur, H.; Rawat, M. An efficient and viable photodegradation of a textile Reactive yellow-86 dye under direct sunlight by multi-structured $\mathrm{Fe}_{2} \mathrm{O}_{3}$ encapsulated with phytochemicals of R. Indica. J. Mater. Sci. Mater. Electron. 2020, 31, 21233-21247. [CrossRef]

45. Madivoli, E.S.; Kareru, P.G.; Maina, E.G.; Nyabola, A.O.; Wanakai, S.I.; Nyang'au, J.O. Biosynthesis of iron nanoparticles using Ageratum conyzoides extracts, their antimicrobial and photocatalytic activity. Sn Appl. Sci. 2019, 1, 1-11. [CrossRef]

46. Alshehri, A.; Malik, M.A.; Khan, Z.; Al-Thabaiti, S.A.; Hasan, N. Biofabrication of Fe nanoparticles in aqueous extract of Hibiscus sabdariffa with enhanced photocatalytic activities. RSC Adv. 2017, 7, 25149-25159. [CrossRef]

47. Kumar, M.R.A.; Ravikumar, C.R.; Nagaswarupa, H.P.; Purshotam, B.; Gonfa, B.; Murthy, H.C.A.; Sabir, F.K.; Tadesse, S. Evaluation of bi-functional applications of $\mathrm{ZnO}$ nanoparticles prepared by green and chemical methods. J. Environ. Chem. Eng. 2019, 7. [CrossRef]

48. Kaliraj, L.; Ahn, J.C.; Rupa, E.J.; Abid, S.; Lu, J.; Yang, D.C. Synthesis of panos extract mediated ZnO nano-flowers as photocatalyst for industrial dye degradation by UV illumination. J. Photochem. Photobiol. B Biol. 2019, 199, 111588. [CrossRef]

49. Lau, G.E.; Abdullah, C.A.C.; Ahmad, W.; Assaw, S.; Zheng, A.L.T. Eco-Friendly Photocatalysts for Degradation of Dyes. Catalysts 2020, 10, 1129. [CrossRef]

50. Kahsay, M.H. Synthesis and characterization of $\mathrm{ZnO}$ nanoparticles using aqueous extract of Becium grandiflorum for antimicrobial activity and adsorption of methylene blue. Appl. Water Sci. 2021, 11, 1-12. [CrossRef]

51. Rupa, E.J.; Kaliraj, L.; Abid, S.; Yang, D.C.; Jung, S.K. Synthesis of a Zinc Oxide Nanoflower Photocatalyst from Sea Buckthorn Fruit for Degradation of Industrial Dyes in Wastewater Treatment. Nanomaterials 2019, 9, 1692. [CrossRef] [PubMed]

52. Seo, K.H.; Markus, J.; Soshnikova, V.; Oh, K.H.; Anandapadmanaban, G.; Perez, Z.E.J.; Mathiyalagan, R.; Kim, Y.J.; Yang, D.C. Facile and green synthesis of zinc oxide particles by Stevia Rebaudiana and its in vitro photocatalytic activity. Inorg. Nano-Met. Chem. 2019, 49, 1-6. [CrossRef]

53. Tavakoli, F.; Badiei, A. Facile Synthesis of $\mathrm{Zn}-\mathrm{TiO}_{2}$ Nanostructure, Using Green Tea as an Eco-Friendly Reducing Agent for Photodegradation of Organic Pollutants in Water. Pollution 2018, 4, 687-696. [CrossRef]

54. Aragaw, S.G.; Sabir, F.K.; Andoshe, D.M.; Zelekew, O.A. Green synthesis of $\mathrm{p}-\mathrm{Co}_{3} \mathrm{O}_{4} / \mathrm{n}-\mathrm{ZnO}$ composite catalyst withEichhornia Crassipesplant extract mediated for methylene blue degradation under visible light irradiation. Mater. Res. Express 2020, 7 , 095508. [CrossRef]

55. Fouda, A.; Salem, S.S.; Wassel, A.R.; Hamza, M.F.; Shaheen, T.I. Optimization of green biosynthesized visible light active $\mathrm{CuO} / \mathrm{ZnO}$ nano-photocatalysts for the degradation of organic methylene blue dye. Heliyon 2020, 6, e04896. [CrossRef]

56. Alharthi, F.A.; Alghamdi, A.A.; Al-Zaqri, N.; Alanazi, H.S.; Alsyahi, A.A.; El Marghany, A.; Ahmad, N. Facile one-pot green synthesis of Ag-ZnO Nanocomposites using potato peeland their Ag concentration dependent photocatalytic properties. Sci. Rep. 2020, 10, 1-14. [CrossRef]

57. Khan, M.S.; Dhavan, P.P.; Jadhav, B.L.; Shimpi, N.G. Ultrasound-Assisted Green Synthesis of Ag-Decorated ZnO Nanoparticles UsingExcoecaria agallochaLeaf Extract and Evaluation of Their Photocatalytic and Biological Activity. Chemistryselect 2020, 5 , 12660-12671. [CrossRef]

58. Yulizar, Y.; Eprasatya, A.; Apriandanu, D.O.B.; Yunarti, R.T. Facile synthesis of $\mathrm{ZnO} / \mathrm{GdCoO}_{3}$ nanocomposites, characterization and their photocatalytic activity under visible light illumination. Vacuum 2021, 183, 109821. [CrossRef]

59. Ahmad, M.; Rehman, W.; Khan, M.M.; Qureshi, M.T.; Gul, A.; Haq, S.; Ullah, R.; Rab, A.; Menaa, F. Phytogenic fabrication of ZnO and gold decorated $\mathrm{ZnO}$ nanoparticles for photocatalytic degradation of Rhodamine B. J. Environ. Chem. Eng. 2021, 9, 104725. [CrossRef]

60. Zelekew, O.A.; Aragaw, S.G.; Sabir, F.K.; Andoshe, D.M.; Duma, A.D.; Kuo, D.H.; Chen, X.Y.; Desissa, T.D.; Tesfamariam, B.B.; Feyisa, G.B.; et al. Green synthesis of Co-doped $\mathrm{ZnO}$ via the accumulation of cobalt ion onto Eichhornia crassipes plant tissue and the photocatalytic degradation efficiency under visible light. Mater. Res. Express 2021, 8, 025010. [CrossRef]

61. Konstantinou, I.K.; Albanis, T.A. $\mathrm{TiO}_{2}$-assisted photocatalytic degradation of azo dyes in aqueous solution: Kinetic and mechanistic investigations-A review. Appl. Catal. B Environ. 2004, 49, 1-14. [CrossRef]

62. Mahshid, S.; Askari, M.; Ghamsari, M.S. Synthesis of $\mathrm{TiO}_{2}$ nanoparticles by hydrolysis and peptization of titanium isopropoxide solution. J. Mater. Process. Technol. 2007, 189, 296-300. [CrossRef]

63. Fujishima, A.; Zhang, X.T.; Tryk, D.A. $\mathrm{TiO}_{2}$ photocatalysis and related surface phenomena. Surf. Sci. Rep. 2008, 63, 515-582. [CrossRef]

64. Wen, Z.H.; Ci, S.Q.; Mao, S.; Cui, S.M.; Lu, G.H.; Yu, K.H.; Luo, S.L.; He, Z.; Chen, J.H. TiO 2 nanoparticles-decorated carbon nanotubes for significantly improved bioelectricity generation in microbial fuel cells. J. Power Sources 2013, 234, 100-106. [CrossRef] 
65. Schneider, J.; Matsuoka, M.; Takeuchi, M.; Zhang, J.L.; Horiuchi, Y.; Anpo, M.; Bahnemann, D.W. Understanding TiO 2 Photocatalysis: Mechanisms and Materials. Chem. Rev. 2014, 114, 9919-9986. [CrossRef]

66. Chiarello, G.L.; Dozzi, M.V.; Selli, E. TiO 2 -based materials for photocatalytic hydrogen production. J. Energy Chem. 2017, 26, 250-258. [CrossRef]

67. Binaeian, E.; Seghatoleslami, N.; Chaichi, M.J.; Tayebi, H.A. Preparation of titanium dioxide nanoparticles supported on hexagonal mesoporous silicate (HMS) modified by oak gall tannin and its photocatalytic performance in degradation of azo dye. Adv. Powder Technol. 2016, 27, 1047-1055. [CrossRef]

68. Nabi, G.; Raza, W.; Tahir, M.B. Green Synthesis of $\mathrm{TiO}_{2}$ Nanoparticle Using Cinnamon Powder Extract and the Study of Optical Properties. J. Inorg. Organomet. Polym. Mater. 2020, 30, 1425-1429. [CrossRef]

69. Ahmad, W.; Jaiswal, K.K.; Soni, S. Green synthesis of titanium dioxide $\left(\mathrm{TiO}_{2}\right)$ nanoparticles by using Mentha arvensis leaves extract and its antimicrobial properties. Inorg. Nano Met. Chem. 2020, 50, 1032-1038. [CrossRef]

70. Sonker, R.K.; Hitkari, G.; Sabhajeet, S.R.; Sikarwar, S.; Rahul; Singh, S. Green synthesis of $\mathrm{TiO}_{2}$ nanosheet by chemical method for the removal of Rhodamin B from industrial waste. Mater. Sci. Eng. B Adv. Funct. Solid-State Mater. 2020, 258, 114577. [CrossRef]

71. Aslam, M.; Abdullah, A.Z.; Rafatullah, M. Recent development in the green synthesis of titanium dioxide nanoparticles using plant-based biomolecules for environmental and antimicrobial applications. J. Ind. Eng. Chem. 2021, 98, 1-16. [CrossRef]

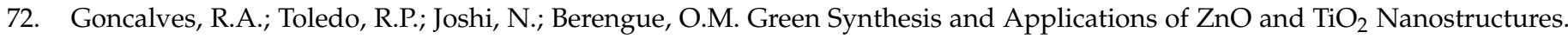
Molecules 2021, 26, 2236. [CrossRef] [PubMed]

73. Zhu, Y.Y.; Ling, Q.; Liu, Y.F.; Wang, H.; Zhu, Y.F. Photocatalytic H-2 evolution on $\mathrm{MoS2}_{2}-\mathrm{TiO}_{2}$ catalysts synthesized via mechanochemistry. Phys. Chem. Chem. Phys. 2015, 17, 933-940. [CrossRef]

74. Sun, S.J.; Ding, H.; Luo, Q.; Chen, S.J. The preparation of silica- $\mathrm{TiO}_{2}$ composite by mechanochemistry method and its properties as a pigment. Mater. Res. Innov. 2015, 19, S269-S272. [CrossRef]

75. Wang, Y.F.; Saitow, K. Mechanochemical Synthesis of Red-Light-Active Green $\mathrm{TiO}_{2}$ Photocatalysts with Disorder: Defect-Rich, with Polymorphs, and No Metal Loading. Chem. Mater. 2020, 32, 9190-9200. [CrossRef]

76. Antony, D.; Yadav, R. Facile fabrication of green nano pure $\mathrm{CeO}_{2}$ and $\mathrm{Mn}$-decorated $\mathrm{CeO}_{2}$ with Cassia angustifoliaseed extract in water refinement by optimal photodegradation kinetics of malachite green. Environ. Sci. Pollut. Res. 2021, 28, 18589-18603. [CrossRef]

77. Rabiee, N.; Bagherzadeh, M.; Kiani, M.; Ghadiri, A.M.; Etessamifar, F.; Jaberizadeh, A.H.; Shakeri, A. Biosynthesis of Copper Oxide Nanoparticles with Potential Biomedical Applications. Int. J. Nanomed. 2020, 15, 3983-3999. [CrossRef] [PubMed]

78. Alhebshi, N.; Huang, H.; Ghandour, R.; Alghamdi, N.K.; Alharbi, O.; Aljurban, S.; He, J.H.; Al-Jawhari, H. Green synthesized $\mathrm{CuxO@Cu} \mathrm{nanocomposites} \mathrm{on} \mathrm{a} \mathrm{Cu}$ mesh with dual catalytic functions for dye degradation and hydrogen evaluation. J. Alloy. Compd. 2020, 848, 156284. [CrossRef]

79. Navada, K.M.; Nagaraja, G.K.; D'Souza, J.N.; Kouser, S.; Ranjitha, R.; Manasa, D.J. Phyto assisted synthesis and characterization of Scoparia dulsisL.leaf extract mediated porous nano $\mathrm{CuO}$ photocatalysts and its anticancer behavior. Appl. Nanosci. 2020, 10, 4221-4240. [CrossRef]

80. Fatimah, I.; Sahroni, I.; Muraza, O.; Doong, R.A. One-pot biosynthesis of $\mathrm{SnO}_{2}$ quantum dots mediated by Clitoria ternatea flower extract for photocatalytic degradation of rhodamine B. J. Environ. Chem. Eng. 2020, 8, 103879. [CrossRef]

81. Mohamed, H.E.A.; Sone, B.T.; Khamlich, S.; Coetsee-Hugo, E.; Swart, H.C.; Thema, T.; Sbiaa, R.; Dhlamini, M.S. Biosynthesis of $\mathrm{BiVO}_{4}$ nanorods using Callistemon viminalis extracts: Photocatalytic degradation of methylene blue. Mater. Today Proc. 2021, 36, 328-335. [CrossRef]

82. Munoz-Batista, M.J.; Kubacka, A.; Fernandez-Garcia, M. Effect of g- $\mathrm{C}_{3} \mathrm{~N}_{4}$ loading on $\mathrm{TiO}_{2}$-based photocatalysts: UV and visible degradation of toluene. Catal. Sci. Technol. 2014, 4, 2006-2015. [CrossRef]

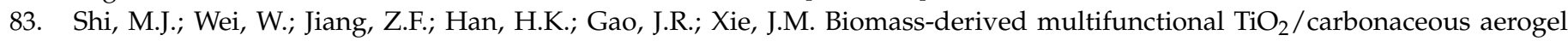
composite as a highly efficient photocatalyst. RSC Adv. 2016, 6, 25255-25266. [CrossRef]

84. Wei, W.; Hu, H.H.; Huang, Z.Y.; Jiang, Z.F.; Lv, X.M.; Xie, J.M.; Kong, L.R. $\mathrm{BiPO}_{4}$ nanorods anchored in biomass-based carbonaceous aerogel skeleton: A 2D-3D heterojunction composite as an energy-efficient photocatalyst. J. Supercrit. Fluids 2019, 147, 33-41. [CrossRef]

85. Djellabi, R.; Zhao, X.; Bianchi, C.L.; Su, P.D.; Ali, J.; Yang, B. Visible light responsive photoactive polymer supported on carbonaceous biomass for photocatalytic water remediation. J. Clean. Prod. 2020, 269, 122286. [CrossRef]

86. Yu, X.N.; Liu, Z.X.; Wang, Y.M.; Luo, H.Y.; Tang, X. Fabrication of corncob-derived biomass charcoal decorated g-C ${ }_{3} \mathrm{~N}_{4}$ photocatalysts for removing 2-mercaptobenzothiazole. New J. Chem. 2020, 44, 15908-15918. [CrossRef]

87. Zhu, Z.; Ma, C.C.; Yu, K.S.; Lu, Z.Y.; Liu, Z.; Huo, P.W.; Tang, X.; Yan, Y.S. Synthesis Ce-doped biomass carbon-based g-C ${ }_{3} N_{4}$ via plant growing guide and temperature-programmed technique for degrading 2-Mercaptobenzothiazole. Appl. Catal. B Environ. 2020, 268, 118432. [CrossRef]

88. Liang, W.; Pan, J.H.; Duan, X.J.; Tang, H.; Xu, J.; Tang, G.G. Biomass carbon modified flower-like $\mathrm{Bi}_{2} \mathrm{WO}_{6}$ hierarchical architecture with improved photocatalytic performance. Ceram. Int. 2020, 46, 3623-3630. [CrossRef]

89. Wang, T.; Liu, X.Q.; Han, D.L.; Ma, C.C.; Wei, M.B.; Huo, P.W.; Yan, Y.S. Biomass derived the V-doped carbon $/ \mathrm{Bi}_{2} \mathrm{O}_{3}$ composite for efficient photocatalysts. Environ. Res. 2020, 182, 108998. [CrossRef] [PubMed] 
90. Sun, J.; Lin, X.M.; Xie, J.; Zhang, Y.Z.; Wang, Q.; Ying, Z.R. Facile synthesis of novel ternary g-C $\mathrm{C}_{4} /$ ferrite/biochar hybrid photocatalyst for efficient degradation of methylene blue under visible-light irradiation. Colloids Surf. A Physicochem. Eng. Asp. 2020, 606, 125556. [CrossRef]

91. Mondol, B.; Sarker, A.; Shareque, A.M.; Dey, S.C.; Islam, M.T.; Das, A.K.; Shamsuddin, S.M.; Molla, M.A.; Sarker, M. Preparation of Activated Carbon/ $\mathrm{TiO}_{2}$ Nanohybrids for Photodegradation of Reactive Red-35 Dye Using Sunlight. Photochem 2021, 1, 54-66. [CrossRef]

92. Islam, S.E.; Hang, D.R.; Chen, C.H.; Chou, M.M.C.; Liang, C.T.; Sharma, K.H. Rational design of hetero-dimensional C-ZnO/MoS 2 nanocomposite anchored on 3D mesoporous carbon framework towards synergistically enhanced stability and efficient visiblelight-driven photocatalytic activity. Chemosphere 2021, 266, 129148. [CrossRef]

93. dos Santos, G.S.; Goes, C.M.; de Sousa, J.G.M.; de Moraes, N.P.; Chaguri, L.; Rodrigues, L.A. Evaluation of ZnO/Carbon Xerogel Composite as a Photocatalyst for Solar and Visible Light Degradation of the Rhodamine B Dye. J. Nanosci. Nanotechnol. 2021, 21, 2292-2301. [CrossRef]

94. Zhao, C.; Ran, F.L.; Dai, L.; Li, C.Y.; Zheng, C.Y.; Si, C.L. Cellulose-assisted construction of high surface area Z-scheme C-doped $\mathrm{g}-\mathrm{C}_{3} \mathrm{~N}_{4} / \mathrm{WO}_{3}$ for improved tetracycline degradation. Carbohydr. Polym. 2021, 255, 117343. [CrossRef]

95. Duan, L.Y.; Li, G.Q.; Zhang, S.T.; Wang, H.Y.; Zhao, Y.L.; Zhang, Y.F. Preparation of S-doped g- $\mathrm{C}_{3} \mathrm{~N}_{4}$ with $\mathrm{C}$ vacancies using the desulfurized waste liquid extracting salt and its application for NOx removal. Chem. Eng. J. 2021, 411, 128551. [CrossRef]

96. Donar, Y.O.; Bilge, S.; Sinag, A. Utilisation of lignin as a model biomass component for preparing a highly active photocatalyst under UV and visible light. Mater. Sci. Semicond. Process. 2020, 118, 105151. [CrossRef]

97. Geng, A.B.; Xu, L.J.; Gan, L.; Mei, C.T.; Wang, L.J.; Fang, X.Y.; Li, M.R.; Pan, M.Z.; Han, S.G.; Cui, J.Q. Using wood flour waste to produce biochar as the support to enhance the visible-light photocatalytic performance of BiOBr for organic and inorganic contaminants removal. Chemosphere 2020, 250, 126291. [CrossRef]

98. Mushtaq, F.; Zahid, M.; Mansha, A.; Bhatti, I.A.; Mustafa, G.; Nasir, S.; Yaseen, M. $\mathrm{MnFe}_{2} \mathrm{O}_{4}$ /coal fly ash nanocomposite: A novel sunlight-active magnetic photocatalyst for dye degradation. Int. J. Environ. Sci. Technol. 2020, 17, 4233-4248. [CrossRef]

99. Shen, X.L.; Zhu, Z.L.; Zhang, H.; Di, G.L.; Chen, T.; Qiu, Y.L.; Yin, D.Q. Carbonaceous composite materials from calcination of azo dye-adsorbed layered double hydroxide with enhanced photocatalytic efficiency for removal of Ibuprofen in water. Environ. Sci. Eur. 2020, 32, 1-15. [CrossRef]

100. Kumar, A.; Choudhary, P.; Kumar, K.; Krishnan, V. Plasmon induced hot electron generation in two dimensional carbonaceous nanosheets decorated with Au nanostars: Enhanced photocatalytic activity under visible light. Mater. Chem. Front. 2021, 5, 1448-1467. [CrossRef]

101. Daulbayev, C.; Sultanov, F.; Korobeinyk, A.V.; Yeleuov, M.; Azat, S.; Bakbolat, B.; Umirzakov, A.; Mansurov, Z. Bio-waste-derived few-layered graphene $/ \mathrm{SrTiO}_{3} / \mathrm{PAN}$ as efficient photocatalytic system for water splitting. Appl. Surf. Sci. 2021, $549,149176$. [CrossRef]

102. Leary, R.; Westwood, A. Carbonaceous nanomaterials for the enhancement of $\mathrm{TiO}_{2}$ photocatalysis. Carbon 2011, 49, 741-772. [CrossRef]

103. Ong, W.J.; Tan, L.L.; Ng, Y.H.; Yong, S.T.; Chai, S.P. Graphitic Carbon Nitride $\left(\mathrm{g}_{-} \mathrm{C}_{3} \mathrm{~N}_{4}\right)$-Based Photocatalysts for Artificial Photosynthesis and Environmental Remediation: Are We a Step Closer To Achieving Sustainability? Chem. Rev. 2016, 116, 7159-7329. [CrossRef] [PubMed]

104. Nalid, N.R.; Majid, A.; Tahir, M.B.; Niaz, N.A.; Khalid, S. Carbonaceous-TiO 2 nanomaterials for photocatalytic degradation of pollutants: A review. Ceram. Int. 2017, 43, 14552-14571. [CrossRef]

105. Ge, J.; Zhang, Y.; Park, S.J. Recent Advances in Carbonaceous Photocatalysts with Enhanced Photocatalytic Performances: A Mini Review. Materials 2019, 12, 1916. [CrossRef]

106. Zuliani, A.; Munoz-Batista, M.J.; Luque, R. Microwave-assisted valorization of pig bristles: Towards visible light photocatalytic chalcocite composites. Green Chem. 2018, 20, 3001-3007. [CrossRef]

107. Cova, C.M.; Zuliani, A.; Santiago, A.R.P.; Caballero, A.; Munoz-Batista, M.J.; Luque, R. Microwave-assisted preparation of $\mathrm{Ag} / \mathrm{Ag}_{2} \mathrm{~S}$ carbon hybrid structures from pig bristles as efficient HER catalysts. J. Mater. Chem. A 2018, 6, 21516-21523. [CrossRef]

108. Cova, C.M.; Zuliani, A.; Munoz-Batista, M.J.; Luque, R. A Sustainable Approach for the Synthesis of Catalytically Active Peroxidase-Mimic ZnS Catalysts. ACS Sustain. Chem. Eng. 2019, 7, 1300-1307. [CrossRef]

109. Lee, S.L.; Chang, C.J. Recent Progress on Metal Sulfide Composite Nanomaterials for Photocatalytic Hydrogen Production. Catalysts 2019, 9, 457. [CrossRef]

110. Nawaukkaratharnant, N.; Sujaridworakun, P.; Mongkolkachit, C.; Wasanapiarnpong, T. Possible use of waste from marcasite jewelry industry as iron pyrite source incorporated with titanium dioxide for photodegradation of lignin under a halogen tungsten lamp. Mater. Lett. 2020, 271, 127778. [CrossRef]

111. Mosaddegh, E. Ultrasonic-assisted preparation of nano eggshell powder: A novel catalyst in green and high efficient synthesis of 2-aminochromenes. Ultrason. Sonochemistry 2013, 20, 1436-1441. [CrossRef]

112. Rahman, M.M.; Netravali, A.N.; Tiimob, B.J.; Rangari, V.K. Bioderived "Green" Composite from Soy Protein and Eggshell Nanopowder. ACS Sustain. Chem. Eng. 2014, 2, 2329-2337. [CrossRef]

113. Ferro, A.C.; Guedes, M. Mechanochemical synthesis of hydroxyapatite using cuttlefish bone and chicken eggshell as calcium precursors. Mater. Sci. Eng. C Mater. Biol. Appl. 2019, 97, 124-140. [CrossRef] 
114. Zhang, X.Y.; He, X.S.; Kang, Z.W.; Cui, M.L.; Yang, D.P.; Luque, R. Waste Eggshell-Derived Dual-Functional CuO/ZnO/Eggshell Nanocomposites: (Photo)catalytic Reduction and Bacterial Inactivation. Acs Sustain. Chem. Eng. 2019, 7, 15762-15771. [CrossRef]

115. Li, Z.H.; Yang, D.P.; Chen, Y.S.; Du, Z.Y.; Guo, Y.L.; Huang, J.L.; Li, Q.B. Waste eggshells to valuable $\mathrm{Co}_{3} \mathrm{O}_{4} / \mathrm{CaCO}_{3}$ materials as efficient catalysts for VOCs oxidation. Mol. Catal. 2020, 483, 110766. [CrossRef]

116. Luo, W.Q.; Ji, Y.P.; Qu, L.; Dang, Z.; Xie, Y.Y.; Yang, C.F.; Tao, X.Q.; Zhou, J.M.; Lu, G.N. Effects of eggshell addition on calcium-deficient acid soils contaminated with heavy metals. Front. Environ. Sci. Eng. 2018, 12, 4. [CrossRef]

117. Sree, G.V.; Nagaraaj, P.; Kalanidhi, K.; Aswathy, C.A.; Rajasekaran, P. Calcium oxide a sustainable photocatalyst derived from eggshell for efficient photo-degradation of organic pollutants. J. Clean. Prod. 2020, 270, 122294. [CrossRef]

118. Gil, A.; Korili, S.A. Management and valorization of aluminum saline slags: Current status and future trends. Chem. Eng. J. 2016, 289, 74-84. [CrossRef]

119. Santamaria, L.; Vicente, M.A.; Korili, S.A.; Gil, A. Saline slag waste as an aluminum source for the synthesis of Zn-Al-Fe-Ti layered double-hydroxides as catalysts for the photodegradation of emerging contaminants. J. Alloys Compd. $2020,843,156007$. [CrossRef]

120. Alberti, S.; Caratto, V.; Peddis, D.; Belviso, C.; Ferretti, M. Synthesis and characterization of a new photocatalyst based on TiO 2 nanoparticles supported on a magnetic zeolite obtained from iron and steel industrial waste. J. Alloys Compd. 2019, 797, 820-825. [CrossRef]

121. Huang, K.; Guo, J.; Xu, Z.M. Recycling of waste printed circuit boards: A review of current technologies and treatment status in China. J. Hazard. Mater. 2009, 164, 399-408. [CrossRef] [PubMed]

122. Zhu, P.; Xia, B.; Li, H.H.; Ma, Y.; Qian, G.R. Visible-Light-Driven Photoreduction of Cr(VI) by Waste-Based Cu $\mathrm{C}_{2} \mathrm{O}$ Photocatalyst from Waste Printed Circuit Boards. Environ. Eng. Sci. 2021, 38, 565-574. [CrossRef]

123. Niu, B.; Chen, Z.Y.; Xu, Z.M. Recycling waste tantalum capacitors to synthesize high value-added $\mathrm{Ta}_{2} \mathrm{O}_{5}$ and polyanilinedecorated $\mathrm{Ta}_{2} \mathrm{O}_{5}$ photocatalyst by an integrated chlorination-sintering-chemisorption process. J. Clean. Prod. 2020, 252, 117206. [CrossRef]

124. Cao, Y.L.; Niu, B.; Sun, H.H.; Xu, Z.M. Synthesizing a high value-added composite photocatalyst using waste capacitors combined with PANI by a mechanical chemistry method. Sustain. Energy Fuels 2021, 5, 2916-2926. [CrossRef]

125. Montoya-Bautista, C.V.; Acevedo-Pena, P.; Zanella, R.; Ramirez-Zamora, R.M. Characterization and Evaluation of Copper Slag as a Bifunctional Photocatalyst for Alcohols Degradation and Hydrogen Production. Top. Catal. 2021, 64, 131-141. [CrossRef]

126. Sheldon, R.A. The E factor 25 years on: The rise of green chemistry and sustainability. Green Chem. 2017, 19, 18-43. [CrossRef]

127. Kleinekorte, J.; Fleitmann, L.; Bachmann, M.; Katelhon, A.; Barbosa-Povoa, A.; von der Assen, N.; Bardow, A. Life Cycle Assessment for the Design of Chemical Processes, Products, and Supply Chains. Annu. Rev. Chem. Biomol. Eng. 2020, 11, 203-233. [CrossRef] [PubMed] 